\title{
3 \\ The OPCAT and the Changes It Will Impose to Prison Monitoring
}

\section{Introduction}

The Optional Protocol to the Convention against Torture and Other Cruel, Inhuman or Degrading Treatment or Punishment (OPCAT) is the most recent international law obligation entered into by Australia relevant to prisons. ${ }^{1}$ Australia signed the OPCAT on 19 May 2009 and ratified it on 15 December 2017. ${ }^{2}$ As outlined in Chapter 2, the OPCAT introduces a dual-level monitoring regime. Monitoring is conducted by both the international Subcommittee for the Prevention of Torture and Other Cruel, Inhuman or Degrading Treatment or Punishment (SPT), which is a United Nations (UN) committee of experts, and by the domestic National Preventive Mechanisms (NPMs) that signatories to the OPCAT are required to establish. Australia has determined that multiple bodies at the federal, state and territory level will form Australia's NPM (due to the

1 Optional Protocol to the Convention against Torture, adopted 18 December 1992, UN Doc A/RES/ 57/199 (entered into force 22 June 2006) ('OPCAT').

2 Minister for Foreign Affairs and Attorney-General (Cth), 'Ratification of OPCAT Caps Year of Significant Human Rights Achievements for Turnbull Government' (Media Release, 15 December 2017). For an analysis of the 'path' to ratification see Richard Harding, 'Australia's Circuitous Path Towards the Ratification of the OPCAT, 2002-2017: The Challenges of Implementation' (2019) 25(1) Australian Journal of Human Rights 4. 
responsibility for places of detention being divided between different levels of government) and that the Commonwealth Ombudsman will perform the coordinating role ${ }^{3}$ (a role that commenced from 1 July 20184).

Australia currently has a wide variety of organisations that monitor, investigate and adjudicate what happens in prisons. These include courts, prison inspectorates, human rights commissions, Ombudsmen, Coroners and Royal Commissions. They provide scrutiny of prison operation in four main ways. First, courts and tribunals can adjudicate claims brought by people in prison. Second, people in prison may make complaints which complaint handling bodies can investigate. Third, investigatory/ monitoring bodies can inspect prisons and prepare reports on the systematic conditions and treatment of imprisoned people. Such reports are usually made publicly available. Finally, Coroners scrutinise deaths in custody and make recommendations about how to avoid similar deaths occurring in the future.

The OPCAT will change prison monitoring in Australia in three significant ways. First, it will subject Australian prisons to international-level scrutiny by an expert committee (the SPT) that will assess Australia's compliance with the international law and standards outlined in Chapter 2. Second, it will shift the current predominantly reactive monitoring system to a preventive system-a system focused specifically on preventing torture, cruel, inhuman or degrading treatment or punishment in line with the Convention against Torture and Other Cruel, Inhuman or Degrading Treatment or Punishment (CAT) which the OPCAT falls under. ${ }^{5}$ Third, it will require monitoring mechanisms to meet the six criteria in the OPCAT for NPM operation-criteria not currently met by Australian monitoring mechanisms.

This chapter will discuss each of these shifts in turn. It will also consider the recent work by the Victorian Ombudsman who undertook an OPCAT-compliant inspection of a women's prison in Victoria (the Dame

3 Australian Human Rights Commission, OPCAT in Australia Consultation Paper (May 2017) 7-8.

4 Australian Human Rights Commission, OPCAT in Australia Consultation Paper: Stage 2 (June 2018) 5 .

5 Convention against Torture and Other Cruel, Inhuman or Degrading Treatment or Punishment, opened for signature 10 December 1984, 1465 UNTS 85 (entered into force 26 June 1987) ('CAT'). Australia ratified the CAT on 10 December 1985. As noted in Chapter 2, other treaties also emphasise the prohibition of torture and cruel, inhuman or degrading treatment or punishment: see International Covenant on Civil and Political Rights, opened for signature 19 December 1966, 999 UNTS 171 (entered into force 23 March 1976) art 7 ('ICCPR'); Convention on the Rights of Persons with Disabilities, opened for signature 30 March 2007, 2515 UNTS 3 (entered into force 3 May 2008) art 15 ('CRPD'). 
Phyllis Frost Centre) to show the differences in approach that were required compared to the type of inspections the Ombudsman would typically carry out of prisons in Victoria. ${ }^{6}$ This is a practical illustration of the difference the OPCAT may make to prison inspections in Australia nationally and it will be referred to throughout this chapter.

It will be obvious from this chapter that the matters either brought before the monitoring mechanisms (as litigation or complaints) or brought to light by the monitoring mechanism's investigatory functions paint a very bleak picture of the practices in Australian prisons. Therefore, in addition to explaining the differences that OPCAT will make to prison monitoring, the discussion below will also provide numerous justifications for the prerequisites for human rights compliance set out in the remaining chapters of this book.

\section{The International Subcommittee for the Prevention of Torture}

The SPT is comprised of 25 experts with varied backgrounds from countries that have ratified the OPCAT. ${ }^{7}$ They carry out visits to places where people are deprived of their liberty in countries that have ratified the OPCAT. Such visits involve at least two members of the SPT and there are four types of visits: 'SPT country visits, SPT country followup visits, NPM advisory visits and OPCAT advisory visits'. ${ }^{8}$ Following a visit, the SPT will provide a confidential report to the state party which is published only if the state party requests this. ${ }^{9}$ The SPT has guiding principles to inform their overall approach as well as guidelines for their approach to country visits. ${ }^{10}$

6 Victorian Ombudsman, Implementing OPCAT in Victoria: Report and Inspection of the Dame Phyllis Frost Centre (2017).

7 'Members serve in their individual capacity and are drawn from a variety of different backgrounds relevant to its work, including lawyers, medical professionals and detention and inspection experts': United Nations Office of the High Commission, Factfle on the SPT <https://www.ohchr.org/EN/ HRBodies/OPCAT/Pages/Factfile.aspx>.

8 United Nations Human Rights Office of the High Commissioner, The SPT in Brief<https:// www.ohchr.org/en/hrbodies/opcat/pages/brief.aspx>.

9 OPCAT art 16.

10 SPT, The Approach of the Subcommittee on Prevention of Torture to the Concept of Prevention of Torture and Other Cruel, Inhuman or Degrading Treatment or Punishment Under the Optional Protocol to the Convention Against Torture and Other Cruel, Inhuman or Degrading Treatment or Punishment, CAT/OP/12/6 (30 December 2010); Guidelines of the Subcommittee on Prevention of Torture and Other Cruel, Inhuman or Degrading Treatment or Punishment in Relation to Visits to States Parties Under Article 11 (a) of the Optional Protocol, CAT/OP/5 (14 February 2015). 
By the end of 2019, the OPCAT had been ratified by 90 state parties and signed by a further $13 .{ }^{11}$ The SPT's capacity to visit individual state parties with any frequency is necessarily limited. The Australian Human Rights Commission anticipates that 'the SPT can be expected to conduct a visit to Australia once every seven to ten years'. ${ }^{12}$

The impact of SPT visits on Australia will not be known until they begin, but some insight may be drawn from New Zealand, which ratified the OPCAT in 2007 and was visited by the SPT in 2013. In summarising that experience, McGregor writes:

The SPT after examining 35 places of detention in its 2013 visit to New Zealand said it 'did not encounter any consistent allegations of torture or physical ill treatment' ... The visits are expected to serve as a deterrent to bad behaviour by staff and officials and also to put pressure on authorities to improve transparency and prison conditions. ${ }^{13}$

Hopefully the SPT will have a similar deterrent effect in Australia, and this may serve to counterbalance the lack of frequency of SPT visits. The NPM regime is crucial in this regard because there is a requirement that NPM visits are conducted regularly (as detailed later in this chapter under 'Evaluation of Monitoring Mechanisms in Australia').

\section{Current Monitoring System in Australia}

The major problem with current monitoring practices in Australia is that the system is predominantly reactive- that is, there needs to be a problem (death, harm or human rights violation) before investigation can be initiated (such as court proceedings, complaints investigations and major investigations such as coronial inquests and Royal Commissions). However, there are some proactive elements, such as the inspections carried out by prison inspectorates, Ombudsmen and human rights commissions.

11 United Nations Human Rights Office of the High Commissioner, Status of Ratification Interactive Dashboard <http://indicators.ohchr.org/>.

12 Australian Human Rights Commission, above n 4, 7.

13 Judy McGregor, 'The Challenges and Limitations of OPCAT National Preventive Mechanisms: Lessons From New Zealand' (2017) 23(3) Australian Journal of Human Rights 351, 357. 


\section{Courts and Tribunals}

Courts form an integral part of the independent external monitoring system. Human rights legislation would be greatly devalued if redress from the courts was not available. As Nowak writes, ' $\mathrm{t}]$ ] he very notion of human rights implies that rights-holders must have some possibility to hold duty-bearers accountable for not living up to their legally binding human rights obligations'. ${ }^{14}$ The problem in Australia is the absence of human rights legislation in jurisdictions other than the Australian Capital Territory (ACT), Victoria and Queensland. The operation of this legislation in the ACT and Victoria is considered here because these jurisdictions have had human rights legislation for several years. It is not yet possible to assess the impact of the Queensland legislation because it only commenced on 1 January 2020.

In all jurisdictions, there are considerable practical barriers facing imprisoned people seeking to litigate. These include accessing legal advice while in prison, the expense of legal proceedings and the challenges in accessing information when preparing for their hearing (particularly when self-represented). An example of the latter is the lack of access to computers, which has been the subject of (unsuccessful) litigation in New South Wales (NSW) and Victoria. ${ }^{15}$ Moreover, many people are only in prison for a short sentence and, given the time taken for litigation, any relief granted by the court may not assist the individual during their incarceration. ${ }^{16}$ Nevertheless, a decision of the court may lead to changes in prison operation that benefit other imprisoned people in similar circumstances.

\section{Australian Capital Territory and Victoria}

The ACT and Victoria have explicitly incorporated some of the international human rights protections contained in the International Covenant on Civil and Political Rights (ICCPR) into domestic legislation: the Human Rights Act 2004 (ACT) ('HRA') and Charter of Human Rights

14 Manfred Nowak, 'The Need for a World Court of Human Rights' (2007) 7 Human Rights Law Review 251, 254.

15 Liristis v New South Wales [2018] NSWSC 39; Knight v Deputy Commissioner, Corrections Victoria [2012] VSC 506; Brazel $v$ Westin \& Anor [2013] VSC 527 (3 October 2013). See further Carolyn McKay, 'Digital Access to Justice from Prison: Is There a Right to Technology?' (2018) 42 Criminal Law Journal 303.

16 Anne Owers, 'Prison Inspection and the Protection of Prisoners' Rights' (2010) 30(5) Pace Law Review 1535, 1536. 
and Responsibilities Act 2006 (Vic) ('Charter'). ${ }^{17}$ The details of the rights contained in this legislation are discussed in Chapter 5. This section provides an overview of some key litigation imprisoned people have brought under these Acts.

The approach to seeking a remedy for breach of the rights varies between jurisdictions. In the ACT, it is possible to bring a direct cause of action under the $H R A$ when it is alleged that a public authority has breached their duty. ${ }^{18}$ By contrast, in Victoria, under the Charter, the human rights claim has to be linked to another cause of action. ${ }^{19}$ The cases discussed below will demonstrate that the enforcement mechanisms under both the Charter and $H R A$ provide a relatively weak protection of human rights.

\section{Australian Capital Territory}

The most detailed consideration of the human rights of people in the Alexander Maconochie Centre (AMC) under the HRA has arisen in claims brought by Mr Isa Islam (self-represented). Mr Islam has made claims surrounding his right to:

- education without discrimination (s 27A)

- not to be treated or punished in a cruel, inhuman or degrading way (s 10(1))

- not to be discriminated against on the basis of religion $(s 8(3))^{20}$

- adequate facilities to prepare a criminal appeal (s 22) ${ }^{21}$

- the provision of food consistent with his religious beliefs (s 14). ${ }^{22}$

All of Mr Islam's abovementioned claims have been unsuccessful. The decision relating to the provision of food will be discussed in Chapter 8 and the other claims will be discussed here.

17 Queensland has recently incorporated some ICCPR rights into domestic legislation in the Human Rights Act 2019 (Qld).

18 Human Rights Act 2004 (ACT) s40C(2) ('HRA').

19 Charter of Human Rights and Responsibilities Act 2006 (Vic) s 39(1) ('Charter'). This makes the Charter remedy provision more difficult to rely on in practice compared to the provision in the HRA: see generally Mark Moshinsky, 'Charter Remedies' in Matthew Groves and Colin Campbell (eds), Australian Charters of Rights a Decade On (Federation Press, 2017).

20 Islam v Director-General Justice and Community Safety Directorate (No 3) [2016] ACTSC 27 (25 February 2016).

21 Islam v Director-General, Justice and Community Safety Directorate [2015] ACTCA 60 (16 December 2015).

22 Islam v Director-General of the Department of Justice and Community Safety Directorate [2018] ACTSC 322. 
The ACT Supreme Court held that Mr Islam had had good access to education while imprisoned, having completed three Masters degrees (Mr Islam was also undertaking a doctorate), ${ }^{23}$ and his complaints in relation to education concerned technical problems with the printer and the university's rules about contact with imprisoned people that meant, without Mr Islam giving written consent for AMC staff to liaise with the university, contact would be curtailed. In other words, the limits were due to the combination of university policy and Mr Islam's unwillingness to consent to staff contacting the university on his behalf. ${ }^{24}$

Mr Islam was unable to demonstrate that the allegations concerning cruel, inhuman or degrading treatment met the level of severity required ${ }^{25}$ and unable to show that the 'frustrating and unpleasant' treatment he had been subjected to were causally linked to his religious beliefs. ${ }^{26}$

Mr Islam's claim relating to facilities to prepare for his self-represented sentencing appeal concerned access to a computer and the internet. Mr Islam had free access to a computer shared between 25-26 other imprisoned people, which equated to approximately two hours use per person per week. ${ }^{27} \mathrm{He}$ had the option to hire a computer for his sole use at a cost of $\$ 5$ per week. In either case he would be permitted to access the Austlii online legal database for the purposes of legal research. ${ }^{28}$ Walmsley AJ held that there had been no breach of s 22(2)(b) of the HRA because of these limits to computer access, given that the right is 'not absolute'. ${ }^{29}$ It was further noted that Mr Islam had 'chosen to represent himself' for his appeal..$^{30}$

23 Islam v Director-General Justice and Community Safety Directorate (No 3) [2016] ACTSC 27

(25 February 2016) [161], [121].

24 Ibid [118]-[123]. The following matter also dealt with the right to education and Mr Islam's concerns about printing: Islam v Director-General of the Department of Justice and Community Safety Directorate [2018] ACTSC 322.

25 Ibid [158].

26 Ibid [148].

27 Islam v Director-General, Justice and Community Safety Directorate [2015] ACTCA 60

(16 December 2015) [8]-[10].

28 Ibid [11]-[12].

29 Ibid [26].

30 Ibid [27]. See also the discussion of the decision by McKay, above n 15, 314. 
Mr David Harold Eastman also brought some claims under the HRA prior to a retrial that led to him being released in November 2018. ${ }^{31}$ $\mathrm{Mr}$ Eastman was transferred from a NSW prison to the AMC on 29 May 2009. He had been engaged in cleaning work while in the AMC but submitted that he wanted the opportunity to tutor other imprisoned people. ${ }^{32}$

There is no right to work provided for by the ICCPR. Article 8 precludes forced labour but provides an exception for forced hard labour that is part of a sentence of imprisonment. Work would generally be considered to be a component of rehabilitation as required by art 10(3) of the ICCPR. Although the $H R A$ has not incorporated art 10(3), a number of provisions in the Corrections Management Act 2007 (ACT) require rehabilitation. ${ }^{33}$

Refshauge J reviewed the international case law and concluded that people in prison do not have a right to work in the ACT, although he noted that an opportunity to work may be required under s 19(1) of the $H R A$, which is the right to humane treatment. ${ }^{34}$ His Honour found there was no right for people in the AMC to choose what work they undertake even if there is the opportunity to work. ${ }^{35}$

Mr Eastman also claimed that on a number of occasions prison staff spoke to him in a way that contravened the right to be treated with humanity and respect for human dignity contained in s 19(1) of the HRA-for example, by calling him a 'murderer'. ${ }^{36}$ However, the Court found that in some instances the conduct could not be proven, and in other

31 For an examination of the events that led to Mr Eastman's release see Jacqueline Fuller, 'The David Eastman Case: The Use of Inquiries to Investigate Miscarriages of Justice in Australia' (2020) 45(1) Alternative Law Journal 60.

32 David Harold Eastman v Chief Executive Officer of the Department of Justice and Community Safety [2010] ACTSC 4 (12 January 2010), [50], [54].

33 Paragraph 7 (d) provides that an object of the CMA is 'promoting the rehabilitation of offenders and their reintegration into society'; Section 9, which is about the treatment of detainees generally, provides that ' $[\mathrm{f}]$ unctions under this Act in relation to a detainee must be exercised as follows ... (f) if the detainee is an offender-to promote, as far as practicable, the detainee's rehabilitation and reintegration into society'. For background on the history of the inclusion of these provisions in ACT law see Anita Mackay, 'The Road to the ACT's First Prison (the Alexander Maconochie Centre) was Paved with Rehabilitative Intentions' (2012) 11(1) Canberra Law Review 33.

34 David Harold Eastman v Chief Executive Officer of the Department of Justice and Community Safety [2010] ACTSC 4 (12 January 2010) [99].

35 Ibid [85]-[91] (emphasis added). Another decision relating to the provision of work in the AMC is Islam v Director-General of the Justice and Community Safety Directorate [2015] ACTSC 20.

36 Eastman $v$ Chief Executive of the Department of Justice and Community Safety [2011] ACTSC 33 (4 March 2011) at [26]-[40]. 
instances that the conduct did not amount to a breach of the right. ${ }^{37}$ Such reasoning arguably suggests that much of what imprisoned people might regard as demeaning treatment may be difficult to address through charters of rights.

\section{Victoria}

There have only been three successful cases brought in reliance on the Victorian Charter relating to adult imprisonment. ${ }^{38}$ The first, decided in 2010, involved Ms Castles's challenge to a decision to deny her invitro fertilisation (IVF) treatment while in prison at a clinic outside the prison-Castles $v$ Secretary to the Department of Justice ('Castles'). ${ }^{39}$ The second, decided in 2017, involved Mr Minogue's challenge to gain access to a book that had been mailed to him and then returned to sender in violation of his right to privacy and freedom of expression-Minogue $v$ Dougherty ('Minogue'). ${ }^{40}$ The third, decided in 2018, involved Mr Haigh's challenge to gain access to Tarot cards for the purpose of his religious freedom-Haigh v Ryan ('Haigh'). ${ }^{41}$

Ms Castles applied to have IVF treatment because she would be ineligible for it after her release due to her age. The Supreme Court held that Ms Castles was entitled to IVF treatment under s 47(1)(f) of the Corrections Act 1986 (Vic) (Corrections Act) which provides a right to access medical care and treatment. Despite there being a number of human rights relevant to accessing IVF treatment, ${ }^{42}$ Emerton J's decision was based primarily on an interpretation of $s 47(1)(f)$ (which provides 'the right to have access to

\footnotetext{
37 Ibid [25], [29] and [40].

38 The Victorian Supreme Court has held that imprisoning minors in an adult prison breached the Charter: see Certain Children v Minister for Families and Children \& Ors (No 2) [2017] VSC 251, but as this book does not examine juvenile detention this is not discussed here. For discussion of that decision see Judith Bessant and Rob Watts, 'Child Prisoners, Human Rights, and Human Rights Activism: Beyond "Emergency” and "Exceptionality”-An Australian Case Study' in Gabriel BlouinGenest, Marie-Christine Doran and Sylvie Paquerot (eds), Human Rights as Battlefields: Changing Practices and Contestations (Springer Nature Switzerland, 2019).

39 Castles $v$ Secretary to the Department of Justice and Others (2010) 28 VR 141.

40 Minogue v Dougherty [2017] VSC 724.

41 Haigh $v$ Ryan [2018] VSC 474.

42 Such as the right to privacy against arbitrary interference with one's family contained in s 13(a) of the Charter. The equivalent right under the European Convention for the Protection of Human Rights and Fundamental Freedoms (ECHR) has been held by the European Court of Human Rights (ECtHR) to be violated by restrictions on access to in-vitro fertilisation (IVF) treatment for people in prison in the UK: Dickson v UK [2007] ECHR 1050. See Matthew Groves, 'Prisoners and the Victorian Charter' (2010) 34 Criminal Law Journal 217, 219.
} 
reasonable medical care and treatment necessary for the preservation of health'), with the Charter 'serv[ing] to confirm the interpretation that had been arrived at in any event'. ${ }^{43}$

Emerton J held that s 47(1)(f) needed to be interpreted consistently with the Charter right of imprisoned people to be treated with humanity and respect for their human dignity (contained in s 22(1)). ${ }^{44}$ In interpreting the right to medical care in the Corrections Act consistently with this Charter right, Emerton J went on to find that 'IVF treatment is treatment that is necessary for the preservation of Ms Castles' reproductive health'. ${ }^{45}$ The interpretation of 'preservation of health' to include 'reproductive health' was not necessarily a self-evident one, nor one that had been reached in the many years that the right had been in the Corrections Act (enacted in 1986). It was an 'expansive reading' of the Act, ${ }^{46}$ and one that has been described by Sifris as 'significant from a women's rights perspective. ${ }^{47}$

The Court did consider the application of the Charter to imprisoned people to an extent. The Court held that Ms Castles should not be denied rights other than her liberty, ${ }^{48}$ and that '[1]ike other citizens, prisoners have a right to enjoyment of a variety of facilities, goods, services and conditions necessary for the realisation of a high standard of health. That is to say, the health of a prisoner is as important as the health of any other person'. ${ }^{49}$ However, Emerton J emphasised that this right has to be balanced against the reality of deprivation of liberty. That is, imprisoned people are unable to leave the prison whenever they wish to access medical care. Her Honour opined that 'although prisoners do not forgo their

43 Castles $v$ Secretary to the Department of Justice and Others (2010) 28 VR 141, 146. See also Groves, above n 42, 220. This contributes to Debeljak's conclusion that Castles is a 'Charter-inspired' decision, rather than a 'Charter-based' decision: Julie Debeljak, 'The Rights of Prisoners Under the Victorian Charter: A Critical Analysis of the Jurisprudence on the Treatment of Prisoners and Conditions of Detention' (2015) 38(4) University of New South Wales Law Journal 1332, 1349.

44 Ibid 173.

45 Ibid 174.

46 Matthew Groves, 'The Second Charters of Prisoners' Rights' in Matthew Groves and Colin Campbell (eds), Australian Charters of Rights a Decade On (Federation Press, 2017) 201.

47 Ronli Sifris, 'The Approach of the Victorian Charter to Women's Rights' in Matthew Groves and Colin Campbell (eds), Australian Charters of Rights a Decade On (Federation Press, 2017) 144.

48 Citing the Office of the High Commissioner for Human Rights General Comment in relation to Article 10 of the ICCPR: Castles $v$ Secretary to the Department of Justice and Others (2010) 28 VR 141, 167. This accords with the common law 'residuum principle' discussed in Chapter 2 and Principle 5 of the United Nations Basic Principles for the Treatment of Prisoners cited in Chapter 2.

49 Castles $v$ Secretary to the Department of Justice and Others (2010) 28 VR 141, 169. 
human rights, their enjoyment of many rights and freedoms enjoyed by other citizens will necessarily be compromised by the fact that they have been deprived of their liberty'. ${ }^{50}$

In the Minogue case, Mr Minogue brought four claims relating to his ability to send and receive mail from Barwon prison. The Supreme Court considered the claims under both the Corrections Act and Charter, ${ }^{11}$ however, the focus of this discussion will be on the Charter claims which rested on the rights to privacy and freedom of expression contained in ss 13 and 15(2) respectively. The relevant text of the provisions is as follows:

A person has the right-(a) not to have his or her privacy, family, home or correspondence unlawfully or arbitrarily interfered with; and (b) not to have his or her reputation unlawfully attacked.

Every person has the right to freedom of expression which includes the freedom to seek, receive and impart information and ideas of all kinds, whether within or outside Victoria and whether ... (b) in writing; or (c) in print ...

Only one of Mr Minogue's four claims was found to have breached the Charter. This related to a package containing a book that had been returned to sender by the prison's mail officer. ${ }^{52}$ The officer admitted that she had failed to take into account Mr Minogue's Charter rights (as required by s 38 of the Charter, which imposes duties on public authorities) when making this decision and the Court declared that this was an 'unlawful' interference with Mr Minogue's correspondence and that the officer had not 'given proper consideration' to Mr Minogue's Charter rights. ${ }^{53}$ This remedy was hardly helpful to $\mathrm{Mr}$ Minogue. He received a declaration that his Charter rights had not been properly considered but did not get access to the book that had been returned to the sender.

Mr Minogue's remaining claims related to three other incidents. First, a letter that was seized by the prison and not provided to Mr Minogue on the basis that it was 'unsolicited'. This claim was unsuccessful because

50 Ibid. For in-depth discussions of the Castles decision see Debeljak, above n 43, 1339-51; Groves, above n 46, 198-201; Sifris, above n 47, 141-4.

51 The relevant section of the Corrections Act 1986 (Vic) provides: 'Every prisoner has the following rights - subject to section $47 \mathrm{D}$, the right to send and receive other letters uncensored by prison staff: $s 47(\mathrm{n})$. The dual claim stemmed from the requirement that all Charter claims be attached to another cause of action.

52 Minogue v Dougherty [2017] VSC 724 [36].

53 Ibid [83], [85], [96]. 
the prison had a 'reasonable belief' that the letter 'was a threat to prison security'. This was considered a reasonable limit in accordance with s 7 of the Charter..$^{54}$ Second, the prison's refusal to make 40 copies of an A3-sized newspaper article (relating to Mr Minogue's parole) that Mr Minogue wished to include with his Christmas letter. This claim was unsuccessful because the prison would have photocopied the article in a smaller size (A4) and the Court was of the view that 'there was no impediment' to $\mathrm{Mr}$ Minogue getting 'someone outside the prison' to perform 'this secretarial function for him'. ${ }^{55}$ Therefore, the Court held there had not been an interference with Mr Minogue's right to freedom of expression. ${ }^{56}$ Third, the prison's withholding of a letter containing a bank account statement and an email for investigation prior to their provision to Mr Minogue. This claim was unsuccessful, both because the delay in delivering the letter was held to be justified and because the claim had been brought against the wrong defendant. ${ }^{57}$

In the Haigh case, Mr Haigh had been denied four Tarot cards from the deck, which he argued breached his right to freedom of religion and freedom of expression protected by ss 14 and 15 of the Charter respectively. The claim also relied upon the right to practice a religion of choice protected by s 47(1)(i) of the Corrections Act (as the cause of action to which the Charter claim was attached).

There was no dispute that Mr Haigh's religion was Paganism (a religion recognised by Corrections Victoria), or that Tarot cards were one element of the practice of this religion. ${ }^{58}$ The General Manager of the prison withheld the four cards that were the subject of the litigation because they displayed 'objectionable material'. ${ }^{59}$ The Court found that there were reasonable grounds upon which such a conclusion could be reached, including that the cards might 'offend some prison staff' and be 'used

\footnotetext{
54 Ibid [3], [55], [79].

55 Ibid [21], [61].

56 Ibid [80].

57 Ibid [33]-[34], [66], [52]. For this reason no consideration to the Charter was given: ibid [82].

58 Haigh v Ryan [2018] VSC 474, [7]-[9]. Corrections Victoria therefore have an inclusive definition of religion for the purposes of the relevant Acts because the definition included Nature Religions: ibid [9]. Mr Haigh had previously been denied access to Tarot cards, but, following a complaint to the Victorian Equal Opportunity and Human Rights Commission, he was given access to Tarot cards excluding the four cards that were the subject of this litigation: ibid [22]-[23], [34].

59 Ibid [34].
} 
to influence other prisoners' and that decisions about such matters fall within the responsibilities of the General Manager to ensure 'security and good order' in the prison. ${ }^{60}$

This aspect of the decision was similar to the Minogue case; namely, that the General Manager had failed to take into account Mr Haigh's Charter rights when deciding whether to allow Mr Haigh access to the Tarot cards - a fact that the General Manager admitted to the Court. ${ }^{61}$ The Court made no finding on whether Mr Haigh was entitled to have access to the withheld Tarot cards and instead ordered that the General Manager remake the decision. ${ }^{62}$ The Court emphasised its decision was limited to requiring that Charter rights be 'given proper consideration' when a request relating to religious practice is made. ${ }^{63}$

The reasoning in both the Minogue and Haigh cases imply that the Charter rights could have been properly considered and the limitation on those rights held to be justified (whether for the purposes of maintaining 'security and good order', or reasons relating to prison administration). If such, the result would be the same (denial of the book and Tarot cards). Both cases concerned important human rights of imprisoned people (privacy, freedom of religion and freedom of expression), yet both decisions gave considerable emphasis to the prison administrators' authority to control the prison and curtail human rights in the process of doing so. This is consistent with the long-held deference of courts to prison administrators. It may also be seen as an abdication of the Court's responsibility to protect the human rights that the Victorian Parliament has chosen to confer on all of its citizens. These are both matters that will be returned to below.

In other Victorian cases concerning prison conditions, the Charter has not been raised even when there was ample scope to argue that human rights were infringed. For example, in Collins v the Queen ${ }^{64}$ ('Collins'), the Charter was not relied upon, despite the evidence that $\mathrm{Mr}$ Collins was locked in his cell for 23 hours per day in a high security unit and may have

60 Ibid [60]-[61].

61 Ibid [68]-[69] (in relation to s 14 of the Charter), [74]-[76] (in relation to s 15 of the Charter).

62 Ibid [98], [100].

63 Ibid [102].

64 [2012] VSCA 163, [12], [4], [7]. Mr Collins's counsel did not raise Charter arguments. The judgment states: 'during the hearing, the Court asked the appellant's counsel whether he was making any submissions based on the Charter of Human Rights and Responsibilities. Counsel expressly disavowed any reliance on the Charter. It is therefore unnecessary to consider whether the Charter has any effect on the legality of the continued detention of the appellant in the present conditions': at [12]. 
been subjected to such a regime for a number of years into the future. The international human rights law position is clear on the use of solitary confinement. As noted in Chapter 2, the Human Rights Committee has clarified that 'prolonged solitary confinement' may amount to 'torture, cruel, inhuman or degrading treatment or punishment' (as prohibited by art 7 of the ICCPR), which has been incorporated into Victorian law by s 10 of the Charter. ${ }^{65}$ The UN Standard Minimum Rules for the Treatment of Prisoners (the Nelson Mandela Rules) Rule 44 provides definitions of 'solitary confinement' and 'prolonged solitary confinement' as follows: 'solitary confinement shall refer to the confinement of prisoners for 22 hours or more a day without meaningful human contact. Prolonged solitary confinement shall refer to solitary confinement for a time period in excess of 15 consecutive days'. Therefore, Mr Collins's treatment constitutes prolonged solitary confinement within the meaning of international law. ${ }^{66}$ An analysis of Collins and other Victorian decisions led Debeljak to conclude that ' $[\mathrm{p}]$ risoners have much to gain from the Charter, but surprisingly this is not borne out in the jurisprudence ... the Charter "has generated far less litigation concerning prisoners" than comparative jurisdictions with rights instruments ${ }^{9}{ }^{67}$

\section{Concluding Remarks on the Australian Capital Territory and Victoria}

Both the scarcity and outcomes of cases that have been brought in the ACT and Victoria illustrate the extremely limited success of imprisoned people in bringing actions under domestic human rights legislation. $\mathrm{Mr}$ Islam and $\mathrm{Mr}$ Eastman's claims under the $H R A$ were unsuccessful. The Castles case reached an outcome that favoured the applicant (that is, the Court ordered that Ms Castles was entitled to IVF treatment), but the rights provided for in the Charter were not determinative of that outcome. In the Minogue case, only one of Mr Minogue's four claims succeeded. For both Mr Minogue and Mr Haigh, it is easy to envisage the decision being remade with proper consideration to Charter rights and

65 United Nations Human Rights Committee, CCPR General Comment No. 20: Article 7 (Prohibition of Torture, or Other Cruel, Inhuman or Degrading Treatment or Punishment) (10 March 1992) para 6.

66 Another case involving solitary confinement where possible Charter arguments were not raised is Director of Public Prosecutions (Vic) v Foster (Unreported, County Court of Victoria, Judge Gucciardo, 17 February 2014). Debeljak describes the Collins and Foster decisions as 'missed opportunities to avail prisoners of the benefit of rights jurisprudence': above n 43, 1372. Solitary confinement and the Charter are discussed in more detail in Chapter 7.

67 Debeljak, above n 43, 1333, citing Matthew Groves, 'Prisoners and the Victorian Charter' (2010) 34 Criminal Law Journal 217, 217. 
the same conclusion being reached (as justifiable limitations of the human rights). It is also of concern that in other cases, including Collins, human rights claims have not been made where they may have been justified. ${ }^{68}$

\section{Other Jurisdictions}

International conventions do not give rise to domestic obligations in Australia unless they are incorporated into domestic law. ${ }^{69}$ This has been confirmed by the High Court in numerous cases. ${ }^{70}$ The practical effect of this is that imprisoned people in jurisdictions outside the ACT and Victoria cannot directly enforce rights under the Treaties detailed in Chapter 2. For example, in the cases of Minogue $v$ Williams $^{71}$ and Collins $v$ State of South Australia, ${ }^{72}$ imprisoned people sought to rely on the ICCPR. In both instances, the courts confirmed the previously held position that the rights contained in the ICCPR cannot be enforced by individuals via litigation in domestic courts. ${ }^{73}$ This was despite the fact that in Collins $v$ State of South Australia the Court considered that arts 10(1) and 10(2) ${ }^{74}$ of the ICCPR had indeed been violated. ${ }^{75}$

Notwithstanding this, there have been some decisions in jurisdictions that do not have human rights protections that have been relevant to the rights of imprisoned people, particularly the right not to be subjected to prolonged solitary confinement.

68 They were also not relied upon in DPP $v$ Foster \& Ors [2014] VCC 312 when Gucciardo J expressed concern about solitary confinement being imposed on a remandee for 22 or 23 hours per day for a period of 18 months in the Melbourne Remand Centre: at [50]-[53]. Nor were they relied upon in Weaven v Secretary, Department of Justice [2012] VSC 582. See the discussion of the Weaven decision by ibid 1151-2.

69 Koowarta v Bjelke-Petersen (1982) 153 CLR 168. The most well-known example of incorporation into domestic law is Commonwealth anti-discrimination legislation. For other examples see Julie Debeljak, 'Does Australia Need a Bill of Rights?' in Paula Gerber and Melissa Castan (eds), Contemporary Perspectives on Human Rights Law in Australia (Lawbook Co, 2013) 42.

70 See, eg, Kioa $v$ West (1985) 159 CLR 550, 570-1; Dietrich $v$ The Queen (1992) 177 CLR 292, [17].

71 Minogue $v$ Williams (2000) 60 ALD 366.

72 Collins $v$ State of South Australia [1999] SASC 257.

73 For a more detailed discussion of these cases see Bronwyn Naylor, 'Protecting the Human Rights of Prisoners in Australia' in Paula Gerber and Melissa Castan (eds), Contemporary Perspectives on Human Rights Law in Australia (Lawbook Co, 2013) 401-2. For a discussion of two earlier decisions where international human rights arguments were made, but were unsuccessful, see Matthew Groves, 'International Law and Australian Prisons' (2001) 24(1) UNSW Law Journal 17, 54-8 (discussing Binse $v$ Willians [1998] 1 VR 381 and $R v$ Hollingshed and Rodgers (1993) 112 FLR 109).

74 Article 10(1) requires treatment with humanity and with respect for the inherent dignity and art 10 (2) requires unconvicted people to be separated from convicted people.

75 Collins $v$ State of South Australia [1999] SASC 257, [30]. 
In Queensland (prior to the Human Rights Act 2019(Qld)), three Supreme Court decisions concerning the sentencing of three people convicted for contempt of court during a Crime and Misconduct Commission hearing resulted in reducing the sentences of imprisonment from six months to 28 or 42 days on the basis of Applegarth J's ruling that the people in question would be subject to a period of prolonged solitary confinement at the Woodford prison. ${ }^{76}$ This is because all people in this prison are held in solitary confinement for 22 hours per day without access to sunlight during that period. The policy states, '[o] ut of cell time restricted to at least two daylight hours a day'. ${ }^{77}$ Following a review of both international law and research evidence about solitary confinement, ${ }^{78}$ Applegarth J concluded that 'a period of six weeks in solitary confinement is harsh punishment and carries a substantial risk of psychological harm'. ${ }^{79}$ However, this remedy of a reduced sentence provided by direct reference to international law is an anomaly because other cases, such as Minogue $v$ Williams and Collins $v$ State of South Australia, where imprisoned people have sought to rely on rights under the ICCPR have been unsuccessful.

In Tasmania, the Tasmanian Supreme Court found that solitary confinement of 23 hours per day had breached the common law duty of care to ensure safety, as well as s 29(p) of the Corrections Act 1997 (Tas) when read in conjunction with $s 4$ (the guiding principles of that Act) ${ }^{80}$ Section 4(c) provides that 'services and procedures should be fair, equitable and have due regard to personal dignity and individuality, as far as is consistent with the need for appropriate levels of security and control'. Section 29(p) provides 'the right to be provided with information about the rules and conditions which will govern the prisoner's or detainee's behaviour in custody'.

76 Twenty-eight days in Callanan v Attendee X [2013] QSC 340 and Callanan v Attendee $Y$ [2013] QSC 341, and 42 days in Callanan v Attendee Z [2013] QSC 342.

77 Cited by Applegarth J in Callanan v Attendee Z [2013] QSC 342, [27].

78 This included the ICCPR, United Nations Standard Minimum Rules for the Treatment of Prisoners (the Nelson Mandela Rules) and Istanbul Statement on the Use and Effects of Solitary Confinement, adopted on 9 December 2007 at the International Psychological Trauma Symposium: Callanan v Attendee Z [2013] QSC 342, [33]-[44].

79 Ibid [53].

80 Pickett $v$ The State of Tasmania [2011] TASSC 907 (20 April 2011) [5], [6], [12]. A newspaper report suggested that Mr Pickett was confined as such for all but five months of his 14-year sentence, and he has been granted parole: David Killick, 'Troubled Prisoner Adrian Alwyn Pickett Freed After 14 Years' Jail, Almost All of which was Spent in Solitary Confinement', The Mercury (Tasmania), 25 February 2014. 
There were two key features of Mr Pickett's incarceration that led to a finding that these provisions had been breached. The first was that for a period of two years he was not given information about the 'rules and conditions' governing his behaviour. There was a Behaviour Management Program in operation in the unit where he was being held, but he was not aware of the behaviour required to progress through the different stages. The second feature was that Mr Pickett was held in solitary confinement for very long periods on the 'most severe level of the program', which the Court held did not comply with the s 4(c) requirements that he be treated with 'due regard to personal dignity and individuality'. ${ }^{81}$

While this decision did not refer to any international human rights law in the same way as the Queensland Supreme Court decisions did, it is a rights-based decision due to the reference to 'personal dignity' in $s$ 4, which resonates with art 10(1) of the ICCPR, and the reliance on s 29 which affords imprisoned people a number of rights.

\section{Concluding Remarks on Prison Litigation in Australia}

There are very few illustrations of successful prison litigation in Australia. This is partly because Australian courts appear reluctant to interfere in prison administration. ${ }^{82}$ With very few exceptions, imprisoned people have not had the problem rectified or been compensated following bringing action in court. Courts have been open about their reluctance to interfere in prison administration, whether a matter is brought pursuant to corrections legislation or human rights legislation.

In relation to the former, the following decision is illustrative: '[p]rison legislation should ordinarily be interpreted so as to give full scope to the power of correctional authorities to carry out tasks of prison administration and management without undue influence from the Courts'. ${ }^{83}$ There are many other examples of these types of comments by judges. ${ }^{84}$ Groves has observed that ' $[t]$ he main rationale for this position was the fear that judicial intervention of any kind into prison administration would cause

81 Pickett $v$ The State of Tasmania [2011] TASSC 907 (20 April 2011) [8]-[12].

82 It is worth noting that as recently as 1978 the High Court held that the doctrine of 'civil death' - where imprisonment led to the loss of the right to commence legal proceedings-was part of Australian law in Dugan v Mirror Newspapers Ltd (1978) 142 CLR 583. For a more detailed discussion of this history and how it stemmed from the United Kingdom see Groves, above n 46, 188.

83 Anderson v Pavic [2005] VSCA 244, [32] (Nettle JA).

84 For further illustrations see the discussion and footnotes in McKay, above n 15, 308-9. 
chaos by unduly interfering with the functions of prison managers' ${ }^{85}$ Therefore, corrections legislation has not been a useful reactive mechanism for responding to human rights violations in prisons.

It is one thing if corrections legislation is not a useful mechanism for imprisoned people to achieve a court-based remedy. It is far more disappointing and puzzling when it continues in jurisdictions that have specifically chosen to incorporate human rights protections. This has occurred repeatedly in the Victorian Supreme Court, the authoritative interpreter of the Charter's application to prisons. For example, in Rich $v$ Secretary of the Department of Justice, the Court opined that '[d]etermining these allegations would convert the court into a prison regulator ${ }^{86}$ Rush J subsequently held:

It is not for judges, save in the most obvious of cases, to supervise or interfere with the administrative decisions of prison authorities concerning the conduct of prisons and prisoners. While acknowledging that prisoners are in a position of particular disadvantage and any abuse of power by prison authorities is unacceptable '... the Court must avoid becoming enmeshed in the merits of particular decisions. The management of prisons is a particularly difficult and sensitive task involving complex practical considerations and security implications with which the court is not familiar and it is difficult to understand or fully appreciate from the comfort of court surroundings ${ }^{87}$

It is precisely the role of judges to intervene when there is an abuse of power that constitutes a breach of the statutorily protected human rights protections. A more positive sentiment was recently expressed by the ACT Supreme Court, with McWilliam AsJ noting:

There is nothing in the statutory regime which suggests a general principle that a Court's intervention in cases of human rights in prisons should be limited ... the opposite appears to be true, in that the particular vulnerability is recognised in the Act [the $H R A$ ] as being specifically worthy of protection. The prison context is of course relevant, but it features as part of the factual matrix by which the conduct is assessed under the Act. ${ }^{88}$

85 Groves, above n 73, 19

86 Rich $v$ Secretary of the Department of Justice \& Ors [2010] VSC 390, [30]. This was in the context where $\mathrm{Mr}$ Rich was seeking facilities to prepare for his legal case, such as access to a computer. 87 Knight v Shuard [2014] VSC 475 at [33] citing Fyfe v South Australia [2000] SASC 84 at [18] (Martin J). See also Castles v Secretary to the Department of Justice [2010] VSC 310 (9 July 2010) [145], per Emerton J.

88 Islam v Director-General of the Department of Justice and Community Safety Directorate [2018] 
It should also be emphasised that the Court's response to the claim being made in the case in which McWilliam AsJ made these remarks was to find that there was a system in place for provision of special diets for imprisoned people to comply with their religious beliefs (in accordance with the protection of religious freedom under s 14 of the $H R A$ ) and, despite the fact that the system was not communicated to imprisoned people, the Court was not willing to direct prison management about how to discharge their statutory duty. ${ }^{89}$ There was no finding that the $H R A$ had been breached. Therefore, the decision itself did not involve any protection of the human rights of the claimant.

Imprisoned people-even in the jurisdictions that have specifically provided statutory human rights protections-do not seem to have the opportunity to 'hold duty-bearers accountable' (in the words of Nowak). ${ }^{90}$ Given that courts have not proved a successful mechanism for the protection of the human rights of imprisoned people in Australia, it is necessary to look to other monitoring mechanisms to see if they perform better in this regard.

\section{Prison Inspectorates}

Several jurisdictions in Australia, the majority of which do not have human rights legislation, have introduced dedicated prisons-focused monitoring bodies known as 'inspectorates'. They are Western Australia (WA), NSW, Tasmania and the ACT. The ACT is the only one of these that has human rights legislation.

89 Ibid [119]-[122]. The prison was also found not to have breached Mr Islam's right to be treated with humanity and respect afforded in s 19(1) of the HRA: at [132]-[134]. The reasoning was rather circular. The Court noted that Mr Islam did not know about the procedure and the kitchen staff were entitled to rely on the incorrect information they had about his dietary requirements, as follows: ' $\mathrm{t}$ ] he refusal to supply Mr Islam with a vegetarian roll on 2 July 2017, and the failure to supply food that $\mathrm{Mr}$ Islam has ordered on a regular basis, did not arise out of any lack of respect for Mr Islam's humanity or inherent dignity, or otherwise fail to give proper consideration to $\mathrm{Mr}$ Islam's human rights. It arose because of a non-compliance with a procedure, which meant that the AMC kitchen did not have on their system that a processed chicken roll was not appropriate for Mr Islam. This was not the fault of Mr Islam, given he did not know about the procedure, but nor was the failure or refusal a contravention of s 19(1) of the Act, given that the AMC kitchen staff were entitled to rely upon what was recorded on $\mathrm{Mr}$ Islam's electronic record as the registered dietary requirement': at [133].

90 Nowak, above n 14, 254. 
WA was the first Australian jurisdiction to establish an inspectorate when it established the Office of the Inspector of Custodial Services (OICS) in 2003. ${ }^{91}$ The OICS is modelled on Her Majesty's Inspectorate of Prisons (HMIP) in the United Kingdom. It conducts inspections with the self-declared intention of:

- improving public confidence in the justice system;

- ensuring the decent treatment of detained people; and

- ensuring the justice system provides value for money. ${ }^{92}$

Such inspections may be announced or unannounced and each prison is to be inspected every three years. ${ }^{93}$ The Inspector has broad powers 'to do all things necessary or convenient to be done for or in connection with the performance of the Inspector's functions'. ${ }^{94}$ The OICS is required to report to the Minister on findings of inspections it carries out. ${ }^{95}$

NSW became the second jurisdiction to establish an independent statutory-based inspectorate, with an Inspector appointed from 1 October 2013. ${ }^{96}$ When introducing the legislation establishing the Inspectorate, the Hon David Clarke stated that:

The inspector will be an independent statutory role that provides external scrutiny of the standards and operational practices of custodial services in New South Wales. The inspector will provide an independent mechanism for monitoring broader thematic and systemic issues arising out of inspections of adult and juvenile correctional facilities and services. ${ }^{97}$

91 Established by the Inspector of Custodial Services Act 2003 (WA).

92 Government of Western Australia, Office of the Inspector of Custodial Services (OICS), Vision and Mission <http://www.oics.wa.gov.au/about-oics/vision-and-mission/>. An example of the final pointvalue for money-is an OICS report in which the Chief Inspector recommended that a 'master plan for the use of all existing custodial facilities, adult and juvenile, should be developed to better inform future investment decisions': OICS, Directed Review into an Incident at Banksia Hill Detention Centre of 20 January 2013 (2013) x'recommendation 33, xvi).

93 Inspector of Custodial Services Act 2003 (WA) s 19.

94 Ibid $s 27$.

95 Ibid ss 20, 24.

96 Greg Smith MP (Attorney General and Minister for Justice) (NSW), 'Inspector of Custodial Services Appointed' (Media Release, 18 September 2013). NSW has had an Inspector-General of Custodial Services since 1999; established by s 213 of the Crimes (Administration of Sentences) Act 1999 (NSW) in response to a NSW Royal Commission.

97 New South Wales, Parliamentary Debates, Legislative Assembly, 23 May 2012, 11834 (the Hon David Clarke). 
The NSW legislation requires prisons to be inspected once every five years and a report to Parliament on the findings of each inspection. ${ }^{98}$ Although the requirement to inspect each prison is only every five years, the Inspector has the power to visit any prison at any time and can require staff to provide information and documents. ${ }^{99}$ There is also a provision in the NSW Act similar to that in the WA Act, as follows: ' $\mathrm{t}$ ] he Inspector has power to do all things necessary to be done for or in connection with, or reasonably incidental to, the exercise of the Inspector's functions'. ${ }^{100}$

Tasmania passed its Custodial Inspector Act 2016 (Tas) in 2016 and appointed a Custodial Inspector in January 2017. ${ }^{101}$ This implemented a recommendation made in 2011 , following an independent inquiry into the Risdon prison in Tasmania. ${ }^{102}$ Similarly to the OICS, the Tasmanian Office of the Custodial Inspector (TOCI) is required to inspect prisons every three years and report to the Minister on these inspections. ${ }^{103}$ The Minister is then required to table the report in Parliament after 30 days of receipt (that is, there is an initial 30-day embargo period). ${ }^{104}$

The TOCI has a list of enumerated powers, as well as a similar catch-all provision to that found in the WA and NSW legislation: 'to do all things necessary or convenient to be done in connection with the performance and exercise of his or her functions and powers under this Act'. ${ }^{105}$ The ACT also passed legislation establishing the Inspector of Correctional Services in 2017 (Inspector of Correctional Services 2017 (ACT)) in response to the recommendation of an independent inquiry into a death in the AMC in 2016. ${ }^{106}$ The Inspector was appointed in March 2018. ${ }^{107}$

\footnotetext{
98 Inspector of Custodial Services Act 2012 (NSW) s 6.

99 Ibid $s 7$.

100 Ibid $s$.

101 Office of the Custodial Inspector Tasmania, About $U_{s}<$ https://www.custodialinspector.tas.gov. au/about_us>.

102 Mick Palmer, Risdon Prison Complex Inquiry (March 2011). Recommendation 2 was 'That Government establish an independent, competent, inspection authority to provide for the periodic inspection of custodial services and the publication of all inspection reports': at 12 .

103 Custodial Inspector Act 2016 (Tas) s 6(1).

104 Ibid s 15.

105 Ibid $s$ 8(h). The enumerated powers are found in $s$.

106 Independent Inquiry into the Treatment in Custody of Mr Steven Freeman, So Much Sadness in Our Lives' (2016); Minister for Corrections (ACT), 'New Oversight Agency Focused on Improving Care, Safety and Health of Detainees' (Media Release, 16 February 2017).

107 Minister for Corrections (ACT), 'ACT's First Inspector of Correctional Services Begins' (Media Release, 14 March 2018).
} 
The media release announcing the appointment of the Inspector noted that ' $[t]$ he Inspector will take a whole of system focus, to identify areas for improvement and prevent poor practices'. ${ }^{108}$

The ACT is different to the other jurisdictions with inspectorates because there is only one adult prison, which accommodates both females and males, in the jurisdiction (the inspectorate is also responsible for oversight of the ACT's youth justice centre). Therefore, the legislation does not need to stipulate the regularity with which each prison should be visited. The legislation instead provides that the Inspector may enter the prison 'at any time', 'at the inspector's own initiative'. ${ }^{109}$ Another unique feature of the ACT legislation is the requirement for the Inspector to review 'critical incidents', which are defined in the Act to include a death, escape, riot or assault leading to hospitalisation. ${ }^{110}$ The Inspector reported on five critical incidents in 2018-19. ${ }^{111}$

The Inspector is required to report to Parliament within six months of carrying out a review and the legislation provides a detailed list of what this report is to include. ${ }^{12}$ In particular, the report should include 'an assessment about whether the rights under international and territory law of detainees at a correctional centre subject to review are protected'. ${ }^{113}$ This means that the Inspector may refer to international laws in addition to the human rights protections contained in the HRA.

Prison inspectorates tend to prepare three categories of report following their investigations. The first is inspection reports detailing the conditions in a particular prison (in response to the statutory requirement to carry out inspections). The second is reports about the treatment of individuals

108 Ibid.

109 Inspector of Correctional Services 2017 (ACT) s 19(1).

110 Inspector of Correctional Services 2017 (ACT) s 17. Reviews do occur in other jurisdictions. For example, there was an independent review of an incident in WA commissioned by the Director General of the Department of Justice in 2018: Jan Shuard, Critical Incident Review into the Events at Greenough Regional Prison on 24-25 July 2018 (2018). There was also an independent review of the riot at a Victorian remand centre in 2015: Independent Investigation into the Metropolitan Remand Centre Riot, Final Report (December 2015).

111 ACT Inspector of Correctional Services, Critical Incident Reviews <https://www.ics.act.gov.au/ reports-and-publications/critical-incident-reviews>.

112 Inspector of Correctional Services 2017 (ACT) s 27(1)-(2).

113 Inspector of Correctional Services 2017 (ACT) s 27(2)(c) (emphasis added). 
(the least common type of report). ${ }^{114}$ The third is thematic reports about a particular matter across numerous prisons in the jurisdiction. Examples of thematic reports include:

- investigations into funeral attendance by imprisoned people by OICS ${ }^{115}$

- a review of care and wellbeing in Tasmanian prisons by TOCI ${ }^{116}$

- a review of prison clothing and bedding by the NSW Inspector ${ }^{117}$

- a review of access to digital technology by OICS ${ }^{118}$

- a review of how 'radicalised' imprisoned people are managed in NSW prisons by the NSW Inspector. ${ }^{119}$

\section{Human Rights and Anti-Discrimination Commissions}

There is the (national) Australian Human Rights Commission (AHRC), as well as an equal opportunity or anti-discrimination commission in each of the states and territories. It might be reasonable to assume that human rights complaints could be taken to the AHRC. However, the AHRC only has Commonwealth jurisdiction, whereas the majority of people in prison are kept in state and territory prisons pursuant to state legislation. The AHRC consequently has no jurisdiction over imprisoned people in Australia. ${ }^{120}$

114 See, eg, OICS, The Birth at Bandyup Women's Prison in March 2018 (2018).

115 OICS, Access to Funerals and Other Compassionate Leave for People in Custody in Western Australia (2017). This was a follow-up to the earlier review on this subject: OICS, Funeral Attendances by Incarcerated People in Western Australia (2013).

116 Tasmanian Custodial Inspector, Inspection of Adult Custodial Services in Tasmania, 2017 Care and Wellbeing Inspection Report (October 2018).

117 NSW Inspector of Custodial Services, Prison Greens: The Clothing and Bedding of Inmates in NSW (2017).

118 OICS, The Digital Divide: Access to Digital Technology for People in Custody (2018).

119 NSW Inspector of Custodial Services, The Management of Radicalised Inmates in NSW (2018).

120 Groves, above n 73, 40. This was also the subject of litigation in Victoria: Craig William John Minogue v Human Rights and Equal Opportunity Commission [1998] FCA 1283 (12 October 1998). One successful case decided under the Disability Discrimination Act 1992 (Cth) by the Human Rights and Equal Opportunity Commission (HREOC) (the predecessor of the Australian Human Rights Commission) helped improve the treatment of HIV-positive people in West Australian prisons in 1996: $X$ \& Y $v$ State of Western Australia [1996] HREOCA 32 (Unreported, The Hon Robert Nettlefield, 26 November 1996). For a discussion of that decision and detailed consideration of the HREOC jurisdiction see Groves, above n 73, 33-40. 
In addition to receiving complaints from imprisoned people, state and territory human rights and anti-discrimination commissions conduct prison investigations from time to time.

\section{Complaints}

To make a complaint to a state or territory anti-discrimination commission, an imprisoned person must show that they were subject to differential treatment based on one of the prohibited grounds of discrimination, such as age, sexuality, race or religious belief. ${ }^{121}$ It is difficult to get a sense about the number and types of complaints brought by people in prison because the majority of commissions report the numbers of complaints they receive by the grounds of discrimination, rather than the place in which the discrimination took place. Only the Victorian Equal Opportunity and Human Rights Commission regularly provides statistics about the number of enquiries received from persons in prisons. The total number of enquiries received in the three years from 2015-18 was $119 .{ }^{122}$ Not all of these enquiries would necessarily have led to formal complaints.

There is also a scarcity of adjudicated determinations in the antidiscrimination arena. ${ }^{123}$ This is because the legislation either imposes compulsory conciliation, ${ }^{124}$ or encourages conciliation in the first instance. ${ }^{125}$ It is usually only if conciliation is unsuccessful that matters are referred by the Commissioner to a tribunal for determination. There are also time limitations imposed on the receipt of complaints that may disadvantage imprisoned people who do not wish to make the complaint during their incarceration. ${ }^{126}$

121 See, eg, the Anti-Discrimination Act 1991 (Qld) s 7. Other jurisdictions have parts of their legislation pertaining to the various attributes. See further Anti-Discrimination Act 1998 (Tas).

122 Victorian Equal Opportunity and Human Rights Commission, Annual Report 2017/18 (2018) 83. Comprising 28 enquiries in 2015-16, 66 enquiries in 2016-17 and 25 enquiries in 2017-18.

123 In relation to sex discrimination specifically, Thornton's research found that the less than 2 per cent of complaints are heard by a court: Margaret Thornton, 'Sex Discrimination, Courts and Corporate Power' (2008) 36 Federal Law Review 31, 34.

124 For example, conciliation is compulsory in the Australian Capital Territory (ACT) (Human Rights Commission Act 2005 (ACT) s 59) and Victoria (Victorian Civil and Administrative Tribunal Act 1998 (Vic) ss 83, 84).

125 This is the case in the Northern Territory (Anti-Discrimination Act 1992 (NT) ss79, 80), NSW (Anti-Discrimination Act 1977 (NSW) s 91A) and South Australia (Equal Opportunity Act 1984 (SA) s 95(4)).

126 Usually 12 months (eg, Equal Opportunity Act 1984 (WA) s 83; Anti-Discrimination Act 1977 (NSW) s89(2)(b); Anti-Discrimination Act 1991 (Qld) s 138), although in the Northern Territory the limit is six months: Anti-Discrimination Act 1992 (NT) s 65. Most Acts do provide discretion to the Commissioner to extend these time limits. 
The recent case law reveals the mixed success of imprisoned people making complaints under anti-discrimination legislation. There have been two successful claims about the lack of availability of fresh halal meat in Queensland prisons. ${ }^{127}$ In contrast, a claim on behalf of an imprisoned person with gender identity disorder concerning denial of female hormone therapy was held not to be discriminatory because it was based on the Queensland Department of Corrective Services's policy in relation to transgender imprisoned people. ${ }^{128} \mathrm{~A}$ disability discrimination complaint in Victoria claiming that prison cell and transport conditions failed to take into account a back injury was also held not to be unlawful discrimination. ${ }^{129}$

\section{Investigation}

In the same way that anti-discrimination commissions have not been a common avenue for imprisoned people to pursue complaints against prison authorities, they have also been an under-utilised mechanism of systemic review. There have been only four comprehensive systemic reviews about the treatment of women in prisons. They were conducted in the ACT (in 2014), Queensland (in 2006 and 2019) and Victoria (in 2013). ${ }^{130}$

127 Mahommed $v$ State of Queensland [2006] QADT 21 (4 May 2006); Ali v State of Queensland [2013] QCAT 319 (6 August 2013). These are discussed in detail in Chapter 7.

128 Sinden $v$ State of Queensland [2012] QCAT 284.

129 Rainsford v Victoria (2009) EOC 93-468. Two earlier cases dating from 1984 and 1986 are of little ongoing relevance given that the Equal Opportunity Act 1977 (Vic) under which they were decided has since been repealed and replaced by the Equal Opportunity Act 2010 (Vic). The cases were Henderson $v$ Victoria (1984) EOC 92-027 concerning having a child accompany their parent in prison and Clarkson v Governor of the Metropolitan Reception Prison \& Anor (1986) EOC 992-153 concerning the standard of food and accommodation in prison.

130 Australian Capital Territory Human Rights Commission, Human Rights Audit on the Conditions of Detention of Women at the Alexander Maconochie Centre: A Report by the ACT Human Rights and Discrimination Commissioner (2014). See the discussion of this review by Penelope Mathew, 'Taking Stock of the Audit Power' in Matthew Groves and Colin Campbell (eds), Australian Charters of Rights a Decade On (Federation Press, 2017) 63-6; Anti-Discrimination Commission Queensland, Women in Prison 2019: A Human Rights Consultation Report (2019); Anti-Discrimination Commission Queensland, Women in Prison. A Report by the Anti-Discrimination Commission Queensland (2006); Victorian Equal Opportunity and Human Rights Commission, Unfinished Business. Koori Women and the Justice System (2013). 
Only the ACT anti-discrimination commission has conducted a review specifically about the systemic issues facing men in prisons, and this was prior to the AMC being built (ie, the review related to remand centres). ${ }^{131}$ There have been reports by the NSW and Victorian commissions that have raised some concerns about prisons from an anti-discrimination perspective - such as discrimination on the basis of Hepatitis C-but these cannot be described as comprehensive systemic reviews. ${ }^{132}$

\section{Ombudsmen}

There is a Commonwealth Ombudsman which, as noted in the Introduction, has been designated as the coordinating organisation for Australia's NPM. There is also an Ombudsman in each of the states and territories. It becomes quite complicated to understand the jurisdiction of each of these organisations in relation to imprisoned people, not least for the people wishing to make a complaint. Similar to human rights and anti-discrimination commissions, Ombudsmen have both a complaints jurisdiction and an investigative function. ${ }^{133}$

\section{Complaints}

The Ombudsman in any particular jurisdiction provides a useful avenue for complaints of a general nature to be made by people in prison including, but not necessarily, complaints based on human rights. Ombudsmen receive a large number of complaints from people in prison annually. For example, in the 2017-18 financial year, the NSW Ombudsman received 5,144 complaints regarding adult correctional centres (12.6 per cent of a total of 40,687 complaints) and the Victorian Ombudsman 5,389 complaints, (35 per cent of all complaints). ${ }^{134}$ The Western Australian Ombudsman received 415 complaints (34 per cent

131 ACT Human Rights Commission, Human Rights Audit on the Operation of ACT Correctional Facilities Under Corrections Legislation (2007). The ACT Health Services Commissioner reviewed the opioid replacement program in the single prison in the ACT: ACT Health Services Commissioner, Review of the Opioid Replacement Program at the Alexander Maconochie Centre (2018).

132 Anti-Discrimination Board of New South Wales, C Change. Report of the Enquiry into Hepatitis $C$ Related Discrimination (2001) 66-74; Victorian Equal Opportunity and Human Rights Commission, 2013 Report on the Operation of the Charter of Human Rights and Responsibilities (2014) 8-10.

133 These dual functions are what Groves has termed the 'fire fighting' (reactive) function of Ombudsman operations and the 'fire prevention' (proactive) function respectively: Matthew Groves, 'Ombudsmen's Jurisdiction in Prisons' in Marc Hertogh and Richard Kirkham (eds), Research Handbook on the Ombudsman (Edward Elgar Publishing, 2018) 328.

134 These were divided into formal $(709)$ and informal $(4,435)$ complaints: Ombudsman New South Wales, Annual Report 2017-2018 (2018) 5; Victorian Ombudsman, Annual Report 2018 (2018) 32. 
of complaints concerning public agencies). ${ }^{135}$ Most prisons have a free telephone service for people to use to contact the Ombudsman's office in their jurisdiction. ${ }^{136}$ There are also legislative protections in place to ensure that correspondence with the Ombudsman remains confidential. ${ }^{137}$

Groves provides a useful example of an investigation by the WA Ombudsman following the receipt of complaints that ultimately led to positive reforms (though the investigation is not recent, dating from 2002). Complaints were made by females in WA prisons who had suffered pregnancy miscarriages due to the work they were undertaking. An investigation by the Ombudsman found widespread problems, particularly in the information provided to prison staff by medical staff. The result of the investigation was the revision of a number of procedures in WA prisons. ${ }^{138}$

In analysing the jurisdiction of the Ombudsman in relation to imprisoned people, Groves has more recently (in 2018) concluded that 'Ombudsman provide a free and accessible avenue for prisoners to raise complaints about almost every aspect of their treatment. This provides an important right to one of the most vulnerable groups in society'. ${ }^{139}$ Of the two reactive mechanisms-litigation in court and making a complaint-it is possible that making a complaint is more effective. It is certainly the quicker and more cost-effective option and, therefore, more relevant and accessible for people in prison.

The alternative view is put forth by Harding and Morgan who note shortfalls in the approach of Ombudsmen to complaints by imprisoned people. They state that Ombudsmen around Australia 'have all chosen to some extent to devolve primary resolution of the bulk of prisoner complaints to the operational Department' and that 'Ombudsman offices (with the exception of NSW) have virtually abandoned the notion

135 Ombudsman Western Australia, Annual Report 2017-18 (2018) 36.

136 Bronwyn Naylor and Lisa Harrison (with Inez Dussuyer and Rachel Kessel), 'Monitoring Closed Environments: The Role of Oversight Bodies' (Working Paper No 3, 'Applying Human Rights in Closed Environments: A Strategic Framework for Managing Compliance' project, ARC, May 2014) 13 ('Working Paper 3').

137 See, eg, the Corrections Act 1986 (Vic) ss 47(j), 47(m)(iv); Corrections Management Act 2007 (ACT) ss 12(1)(g), 12(1)(h) (latter to be read in conjunction with ss 50 and 51).

138 See discussion in Matthew Groves, 'Ombudsmen's Jurisdiction in Prisons' (2002) 28 Monash University Law Review 181, 189-90.

139 Groves, above n 133, 319. 
of a visits-based process in relation to prisoner complaints'. ${ }^{140}$ This substantiates Biles's earlier conclusion that Ombudsmen 'have not had the radical effect on correctional administration that was envisaged at the time when the positions were created'. ${ }^{141}$

Thus, while it is still likely that making a complaint to the Ombudsman is preferable to litigation, neither of these reactive mechanisms are reliable means of protecting the human rights of imprisoned people in Australia. Ratification of the OPCAT is therefore a welcome development.

\section{Investigations}

In jurisdictions that do not have a specific prison inspectorate, the Ombudsman can carry out 'own motion' investigations that focus on specific areas of concern. ${ }^{142}$ These types of investigation may raise systemic concerns, such as the Victorian Ombudsman's investigation that found, among other things, that overcrowding is leading to increased violence in Victorian prisons and raised concerns about health care provision. ${ }^{143}$ They also examine the impact of policies on the individuals who are subject to them, such as the South Australian investigation into restraint of people in hospital (discussed below).

Human rights concerns are sometimes identified by Ombudsmen. In the case of Victoria, the Ombudsman is required to take into account human rights under the Charter when carrying out investigations. ${ }^{144}$ In the recent OPCAT-compliant investigation, the Ombudsman made extensive references to the Mandela Rules ${ }^{145}$ and Charter. ${ }^{146}$

140 Australian Human Rights Commission, Implementing the Optional Protocol to the Convention Against Torture: Options for Australia. A Report to the Australian Human Rights Commission by Professors Richard Harding and Neil Morgan (Centre for Law and Public Policy, The University of Western Australia) (2008) 26 ('AHRC OPCAT report'). Ibid 36. Concern about Ombudsmen deferring to prison management's version of events was also expressed in interviews in Victorian and Western Australian prisons: Bronwyn Naylor, 'Human Rights and Respect in Prisons: The Prisoners' Perspective' in Bronwyn Naylor, Julie Debeljak and Anita Mackay (eds), Human Rights in Closed Environments (Federation Press, 2014) 120. 141 David Biles, 'Human Rights in Correctional Organisations in Australia and Asia: Some Criminological Observations' in Tom Campbell and Seumas Miller (eds), Human Rights and the Moral Responsibilities of Corporate and Public Sector Organisations (Kluwer Academic Publications, 2004) 198-9. 142 See, eg, Ombudsman Act (NT) s 14(1)(b); Ombudsman Act 1973 (Vic) s 13A(2); Ombudsman Act 1972 (SA) s 13(2); Ombudsman Act 2001 (Qld) s 18.

143 Victorian Ombudsman, Investigation into Deaths and Harms in Custody (2014) 34.

144 Ombudsman Act 1973 (Vic) s 13.

145 United Nations Standard Minimum Rules for the Treatment of Prisoners (the Nelson Mandela Rules), UN Doc A/RES/70/175 (17 December 2015) ('the Mandela Rules'). There were at least 29 references to the Rules in the report: Victorian Ombudsman, above $\mathrm{n} 6$.

146 There are at least 24 references to the Charter in the report: ibid. 
In some other jurisdictions, human rights may be considered even in the absence of human rights legislation, such as the South Australian Ombudsman's investigation into the shackling of imprisoned people while in hospital. ${ }^{147}$ The report was prompted by 'Director's Instructions' issued by the Executive Director of Custodial Services requiring that all imprisoned people be restrained when in hospital receiving treatment regardless of their security classification or the risk of escape, including for end-of-life care and during childbirth. ${ }^{148}$ The report allocated four pages to the consideration of the relevant human rights at the international and national level, ${ }^{149}$ concluding that:

the international and national standards and practice acknowledge that there are instances where the restraining of prisoners is necessary to protect the prisoner or the public. However, it is also universally accepted that in these instances prisoners must be restrained for the minimum time necessary, and with the least restrictive type of restraint possible. ${ }^{150}$

The recommendations included that use of restraints be based on the assessed risk of a person escaping, soft restraints be used instead of chains and pregnant women never be restrained during labour. ${ }^{151}$

There are more jurisdictions in Australia without human rights legislation than jurisdictions with such legislation. Ombudsmen perform an important role even in the absence of human rights legislation. There are nevertheless gaps in their coverage that will be discussed later in this chapter (under 'Evaluation of Monitoring Mechanisms in Australia').

\section{Coronial Inquests}

The role of the Coroner is to investigate deaths in certain circumstances prescribed by legislation. As in other areas of law in a federation such as Australia, there are variations in the precise terms of that legislation. Generally speaking, however, Coroners have jurisdiction over deaths that occur while an individual is in the custody of the state, such as

147 Ombudsman South Australia, Ombudsman Investigation into the Department of Correctional Services in Relation to the Restraining and Shackling of Prisoners in Hospitals (2012).

148 Ibid 1.

149 Ibid 12-15.

150 Ibid 16.

151 Recommendations 2, 3 and 5: ibid 3. 
in police custody or in prison. ${ }^{152}$ The role of the Coroner is to 'make recommendations which enhance public safety by learning from avoidable deaths' and to be 'an Ombudsman for the dead'. ${ }^{153}$

There have been numerous coronial inquests into deaths in prisons that could be discussed. A Victorian example has been chosen because it deals with the over-representation of people with mental illness in the prison population. ${ }^{154}$ The inquest concerned the death of Mr Omerovic in the Melbourne Assessment Prison (MAP). Mr Omerovic had a history of severe mental illness and committed suicide by hanging himself in his cell. ${ }^{155}$ The investigation focused on 'how those responsible for mental health services within MAP responded to his presentation and whether the systems in use reasonably identified the level of risk associated with that presentation'. ${ }^{156}$ The concerns identified by the Coroner included the existence of hanging points in cells where people 'at risk' were accommodated, lack of resourcing of Forensicare (the organisation responsible for mental health services at the MAP) and failures of intake and assessment procedures for identifying and treating mental illness. ${ }^{157}$ These findings are of grave concern at a systemic level in light of the number of imprisoned people with mental illness. Such concerns are also echoed in the Victorian Ombudsman's March 2014 report into an inquiry into deaths and harms in custody. ${ }^{158}$

Freckelton and Ranson have argued that human rights are becoming a 'new and important aspect of the infrastructure of the coronial role', particularly in relation to 'the deaths of vulnerable persons away from public gaze at the hands of the state or within institutions for which the state is responsible'. ${ }^{159}$ Despite this observation, and despite having the Charter, the inquest referred to above does not refer to any breach of the human rights of the deceased.

152 See, eg, Coroners Act 2008 (Vic) s 11 ('Obligation to report death of a person placed in custody or care'); Coroners Act 2009 (NSW) s 23 ('Jurisdiction concerning deaths in custody or as a result of police operations'); Coroners Act 2003 (Qld) ss 8, 10.

153 Ian Freckelton and David Ranson, 'Death Investigation and the Role of the Coroner' in Ian Freckelton and Kerry Peterson (eds), Tensions and Traumas in Health Law (Federation Press, 2017) 561. 154 Another recent example is the inquest into the death of an Aboriginal man in the Alexander Maconochie Centre in the Australian Capital Territory: An Inquest into the Death of Steven Claude Freeman [2018] ACTCD 7.

155 Peter White, Inquest into the Death of Adam Sasha Omerovic, Coroner's Court of Victoria,

24 January 2014.

156 Ibid 2.

157 Ibid 49, 53, 56.

158 Victorian Ombudsman, above n 143.

159 Freckelton and Ranson, above 153, 562. 
This may be contrasted to the inquest into the death of $\mathrm{Mr}$ Ward in WA in a prison transport vehicle, the circumstances of which are discussed below. During the Coroner's inquest, submissions were made by the WA Human Rights and Equal Opportunity Commission about the relevance of the ICCPR to the treatment of Mr Ward. ${ }^{160}$ Accordingly, the Coroner made the following observations:

In the present case for the reasons outlined herein for determining that the quality of the supervision, treatment and care of the deceased in the hours before his death was disgracefully bad, I am satisfied that the deceased was subjected to degrading treatment and he was not treated with humanity and with respect for the inherent dignity of the human person. There has been, therefore, a breach of the ICCPR. ${ }^{161}$

There is no legal consequence from a finding by the WA Coroner that the ICCPR has been breached, but it does provide an additional source of criticism of the correctional administrator's actions. The changes that the WA Government has introduced since this inquest are discussed later in this chapter (under 'Evaluation of Monitoring Mechanisms in Australia').

\section{Royal Commissions and Parliamentary Inquiries}

In certain circumstances where there are widespread problems in the prison system, a broad inquiry may be required. This may be carried out either by a specially appointed Royal Commission of Inquiry or by an existing parliamentary committee. ${ }^{162}$

160 For other examples where human rights commissions have intervened in coronial inquests see Rebecca Scott Bray, 'Death Investigation, Coroners' Inquests and Human Rights' in Leanne Weber et al (eds), The Routledge International Handbook of Criminology and Human Rights (Routledge, 2017) 153. 161 A N Hope, Inquest into Death of Ian Ward, Western Australian Coroner's Court, 2009, 130.

162 There was also a 2017 inquiry by the Australian Law Reform Commission into the incarceration rate of Indigenous people that was referred to in Chapter 1: Australian Law Reform Commission, Pathways to Justice-An Inquiry into the Incarceration Rate of Aboriginal and Torres Strait Islander Peoples, Report No 133 (2017). This is not discussed in this section because it was an unusual inquiry for a Law Reform Commission. Law Reform Commissions typically inquire into the operation of a particular piece of legislation and make recommendations about how the operation of that legislation can be improved (eg, Australian Law Reform Commission, Connection to Country: Review of the Native Title Act 1993 (Cth), Report No 126 (2015)) or inquire into a thematic area of law (eg, the encroachment of Commonwealth laws on 'traditional rights and freedoms': see Australian Law Reform Commission, Traditional Rights and Freedoms-Encroachments by Commonwealth Laws, Report No 129 (2016)). Therefore, they are not generally examining widespread problems in the prison system in the way that Royal Commissions and parliamentary committee inquiries do. 
Federal Royal Commissions are established by the Royal Commissions Act 1902 (Cth), and Royal Commissions can also be established by states and territories. ${ }^{163}$ This legislation provides Royal Commissions with broad powers, such as the ability to compel witnesses to give evidence ${ }^{164}$ and the power to gain search warrants. ${ }^{165}$ There have been 136 Royal Commissions established at the federal level since 1902. ${ }^{166}$

There have been two significant Royal Commissions of relevance to adult imprisonment. ${ }^{167}$ These were the Commonwealth Royal Commission into Aboriginal Deaths in Custody (RCIADIC) that reported in 1991, and the Royal Commission into NSW Prisons that reported in $1978 .{ }^{168}$ The focus of this discussion will be on the RCIADIC because, despite it having concluded more than 25 years ago, there are continuing references to the failure of authorities to implement its recommendations, ${ }^{169}$ including by international experts. ${ }^{170}$

163 States and territories have their own enabling legislation: see, eg, Royal Commissions Act 1968 (WA); Royal Commissions Act 1923 (NSW); Inquiries Act 2014 (Vic); Royal Commissions Act 1917 (SA). 164 Royal Commissions Act 1902 (Cth) s 2. Such as arrest powers for failure to appear: Royal Commissions Act 1902 (Cth) s 6B.

165 Ibid $s 4$.

166 Parliament of Australia, Royal Commissions and Commissions of Inquiry <http://www.aph.gov. au/About_Parliament/Parliamentary_Departments/Parliamentary_Library/Browse_by_Topic/law/ royalcommissions $>$. The most recent Federal Royal Commission commenced is the Royal Commission into National Natural Disaster Arrangements that commenced on 20 February 2020.

167 There has been a Royal Commission concerning juvenile detention in the Northern Territory: see Commonwealth and Northern Territory, Royal Commission into the Protection and Detention of Children in the Northern Territory, Final Report (2017). See also the discussion in Taylah Cramp and Anita Mackay, 'Protecting Victims and Vulnerable Witnesses Participating in Royal Commissions: Lessons from the 2016-2017 Royal Commission into the Protection and Detention of Children in the Northern Territory' (2019) 29(1) Journal of Judicial Administration 3. There are two Royal Commissions currently underway that may consider prisons: Royal Commission into Victoria’s Mental Health System (commenced February 2019) and Royal Commission into Violence, Abuse, Neglect and Exploitation of People with Disability (commenced April 2019).

168 Royal Commission into Aboriginal Deaths in Custody, National Report (1991); Justice Nagle, Report of the Royal Commission into NSW Prisons (Government Printer, 1978). Groves has described the Nagle Royal Commission as 'the most wide-ranging investigation of correctional services and the treatment of prisoners in Australian history': Groves, above n 133, 324.

169 See, eg, Elizabeth Grant, 'Approaches to the Design and Provision of Prison Accommodation and Facilities for Australian Indigenous Prisoners after the Royal Commission into Aboriginal Deaths in Custody' (2014) 17(1) Australian Indigenous Law Review 47; Victorian Ombudsman, above n 143, 6. 170 Human Rights Council, Report of the Special Rapporteur on the Rights of Indigenous Peoples on Her Visit to Australia, UN Doc A/HRC/36/46/Add.2 (8 August 2017) 12-13. Following an earlier visit by the UN Special Rapporteur for Indigenous People, the Rapporteur reported to the Human Rights Council that many of the recommendations of this Royal Commission had not been implemented, and recommended that they be 'fully implemented': United Nations Human Rights Council, Report by the Special Rapporteur on the Situation of Human Rights and Fundamental Freedoms of Indigenous People, James Anaya, Addendum, Situation of Indigenous Peoples in Australia (1 June 2010) 14, 22. The RCIADIC is also more recent than the Nagle Royal Commission and was national in focus (whereas the Nagle Royal Commission focused on NSW prisons). 
The RCIADIC investigated the deaths of 99 Indigenous people in police custody or prison between 1 January 1980 and 31 May 1989. After an extensive inquiry, including public hearings relating to each of the 99 deaths in the location where the death occurred, the report made 339 recommendations. ${ }^{171}$ Marchetti summarises the nature of the recommendations as follows:
The 339 recommendations made by the RCIADIC focused primarily upon the adequacy of police and coronial investigations into deaths in custody; self-determination and empowerment; providing adequate social, educational, vocational and legal services for Indigenous youth; cultural diversity and the need for culturally sensitive practices to be incorporated in the dominant criminal and legal justice systems; managing alcohol and substance abuse; improving police relations with, and treatment of, Indigenous people; improving custodial care; conforming with international obligations; addressing land needs; and the continued recognition of the importance of reconciliation. ${ }^{172}$

Parliamentary inquiries are conducted by committees established to 'investigate specific matters of policy or government administration or performance'. ${ }^{173}$ Similar to Royal Commissions, they may be conducted by either federal, state or territory committees. Such inquiries have been an under-utilised monitoring mechanism in the prison context in Australia. The only recent inquiries of relevance are the WA Community Development and Justice Standing Committee inquiry into 'the efficacy and effectiveness of prisoner education, training and employment strategies', which relates to rehabilitation; the NSW inquiry into the Parklea Correctional Centre; and the NSW inquiry into the increase in the prison population. ${ }^{174}$

171 Elena Marchetti, 'Critical Reflections upon Australia's Royal Commission into Aboriginal Deaths in Custody' (2005) 5 Macquarie Law Journal 103.

172 Ibid 110.

173 Parliament of Australia, Infosheet 4-Committees <http://www.aph.gov.au/about_parliament/house _of_representatives/powers_practice_and_procedure/00_-_infosheets/infosheet_4_-_committees $>$.

174 Community Development and Justice Standing Committee (WA), 'Making Our Prisons Work': An Inquiry into the Efficiency and Effectiveness of Prisoner Education, Training and Employment Strategies (2010); New South Wales, Parliament Legislative Council Portfolio Committee No. 4 - Legal Affairs, Parklea Correctional Centre and Other Operational Issues (2018); Select Committee on the Increase in Prisoner Population (NSW), Final Report (2001). There were some more proactive inquiries conducted in the ACT prior to the construction of a prison there, but these related to planning, rather than prison operation and management. See Standing Committee on Justice and Community Safety, ACT Legislative Assembly, The Proposed ACT Prison Facility: Philosophy and Principles (1999); Standing Committee on Justice and Community Safety, ACT Legislative Assembly, Inquiry into the Establishment of an ACT Prison: Justification and Siting (1999). There have also been earlier inquiries into prisons in particular states, such as: Parliament of Tasmania Legislative Council Select Committee, Correctional Services and Sentencing in Tasmania (1999) and Victorian Parliament Legislative Council, Select Committee of the Legislative Council upon the Victorian Prisons Service, Interim Report (1984). 
Problems in prisons are occasionally identified indirectly during broader inquiries. For example, the Senate Committee inquiry into Justice Reinvestment raised concerns about the prison population being at an 'unacceptable level' and the consequent economic and social costs of this, including deterioration of the health of imprisoned people. ${ }^{175}$ Another example is the Senate Select Committee on Regional and Remote Indigenous Communities broad inquiry into Indigenous communities. This inquiry prepared a discussion paper about the incarceration of Indigenous communities. ${ }^{176}$

\section{Evaluation of Monitoring Mechanisms in Australia}

There are six criteria for effective external monitoring under international law. These derive from the OPCAT specifications for the operation of an NPM. These six criteria will be used to evaluate existing mechanisms in Australia. In summary, they are: (1) independence; (2) expertise; (3) adequate resourcing; (4) regular visits with the aim of providing protection against torture and other cruel, inhuman or degrading treatment or punishment; (5) functions and powers; and (6) implementation of recommendations.

When writing about the appointment of the Commonwealth Ombudsman as the coordinating body for Australia's NPM, McMillan has argued that ' $[\mathrm{t}]$ he designation of the Ombudsman points to the high esteem it has for independence, expertise, balance, efficiency and stakeholder respect'. ${ }^{177}$ If this is accepted, it means that the first and second criteria may be achieved. However, it is important to bear in mind that Australia's NPM will be made up of many more organisations in addition to the Ombudsman, and that there are also other criteria that need to be met.

175 Senate Legal and Constitutional Affairs References Committee, Value of a Justice Reinvestment Approach to Criminal Justice in Australia (2013) 17, 25.

176 Senate Select Committee on Regional and Remote Indigenous Communities, Indigenous Australians, Incarceration and the Criminal Justice System (2010). See also Senate Community Affairs References Committee, Indefinite Detention of People with Cognitive and Psychiatric Impairment in Australia (2016).

177 John McMillan, 'The Ombudsman in Australia: Flourishing, Expanding, Diversifying, Innovating' in Marc Hertogh and Richard Kirkham (eds), Research Handbook on the Ombudsman (Edward Elgar Publishing, 2018) 443. 


\section{Independence}

Article 18(1) of the OPCAT requires that 'State Parties shall guarantee the functional independence of the national preventive mechanisms as well as the independence of their personnel'. The independence criterion has three components, identified by Steinerte: ${ }^{178}$ (1) functional independence, (2) independence of personnel and (3) perceived independence. The independence of NPMs is something that the SPT pays particular attention to when it visits countries, and the SPT will inevitably assess this when it visits Australia. ${ }^{179}$

\section{Functional Independence}

Functional independence has three sub-requirements. The first is that the NPM have 'a clear legislative basis' as stipulated in the SPT guidelines for NPMs. ${ }^{180}$ Denmark and Hungary, both of which have constitutionally established Ombudsmen designated as their NPM, are good examples of what is intended here. ${ }^{181}$

The second is operational independence, meaning that 'an NPM cannot be subject to any orders or instructions by any State authority'. ${ }^{182}$ An example of this is the NPM in the Netherlands which provides a report about investigations to the Secretary or Minister of State who has six weeks to send it to the Parliament' otherwise the NPM 'publishes the report itself'. ${ }^{183}$

The third is financial independence, which stems from the Principles Relating to the Status of National Institutions (The Paris Principles) rather than the OPCAT itself. ${ }^{184}$ This criterion has two aspects. On the one hand is the level of resourcing required for independent operation, which has some overlap with the criterion of adequate resourcing, discussed below.

178 Elina Steinerte, 'The Jewel in the Crown and Its Three Guardians: Independence of National Preventive Mechanisms Under the Optional Protocol to the UN Torture Convention' (2014) 14 Human Rights Law Review 1.

179 Ibid 7, 25-6, including details of reports by the Subcommittee for the Prevention of Torture and Other Cruel, Inhuman or Degrading Treatment or Punishment (SPT) following visits to other countries where they have raised concerns about lack of independence.

180 Ibid 9.

181 Ibid 10.

182 Ibid 12.

183 Ibid 14.

184 Adopted by General Assembly resolution 48/134 of 20 December 1993. Steinerte, above n 178, 14. Steinerte notes that art 18(4) of the OPCAT refers to the Paris Principles: at 15. 
This was a problem when Sweden initially signed the OPCAT, with 'the Parliamentary Ombudsman initially refusing the designation as NPM due to additional resources not being allocated to it to carry out the functions'. ${ }^{185}$ On the other hand, the NPM needs to 'freely decide how its funding is to be utilised' without 'interference' by the Executive. ${ }^{186}$

\section{Independence of Personnel}

Independence of personnel can be achieved by having a transparent selection process, ${ }^{187}$ ensuring that there is no potential conflict of interest and that the NPM has the necessary privileges and immunity (with the latter specified in art 35 of the OPCAT and the former contained in the NPM guidelines produced by the SPT). ${ }^{188}$ In relation to this point, an example of non-compliance may be more enlightening than an example of compliance. The Cambodian NPM is made up of 'an inter-governmental committee, chaired by the Deputy Prime Minister and the Minister of the Interior'. ${ }^{189}$ Thus, there is, by structural design, a lack of independence of personnel from government.

\section{Perceived Independence}

It is important that there is public confidence in NPMs, which is facilitated by the perception of independence from government and managers of places of detention. ${ }^{190}$ This might also make people deprived of their liberty more likely to speak to NPM staff when they conduct investigations. Perceived independence can be fostered by the transparent selection process also required to achieve independence of personnel. ${ }^{191}$ It is also fostered by publication about the work being carried out. ${ }^{192}$ Indeed art 23 of the OPCAT requires that NPM annual reports be 'published and disseminated' by state parties.

185 Anita Mackay, 'Human Rights Law Compliance in Prisons: What Can Australia Learn From the Nordic Approach?' (2014) 20(1) Australian Journal of Human Rights 31, 49.

186 Steinerte, above n 178, 17.

187 As required by the NPM guidelines: ibid 18 .

188 Ibid 19.

189 Ibid.

190 Ibid 19-20.

191 A note by the SPT, cited by ibid 20 .

192 Ibid 21. 


\section{Australian Organisations}

There should be no question about the Commonwealth Ombudsman's independence as the coordinating body for Australia's NPM under the OPCAT. ${ }^{193}$ There have been some examples where Ombudsmen offices in Australia have had their independence compromised by being 'given roles that draw it into political or partisan controversy'; ${ }^{194}$ however, the Commonwealth Ombudsman has been monitoring immigration detention since 2005. ${ }^{195}$ This has some obvious parallels with the role of inspecting prisons and is not an area where the office's independence has been called into question.

Prison inspectorates are obvious choices to be part of the state and territory NPM machinery. WA has announced that the OICS will be the NPM responsible for prisons in that state (as well as other justice system places of deprivation of liberty, such as police cells). ${ }^{196}$ Prison inspectorates are established pursuant to legislation, have their own budget, operate completely separately from prison administrators and report directly to Parliament such that the reports are publicly available. The Commonwealth Ombudsman has deemed them all to have the functional independence required by the OPCAT. ${ }^{197}$

There is legislatively enshrined independence of inspectors. For example, s 7 of the Custodial Inspector Act 2016 (Tas) provides that 'In performing his or her functions, the Inspector must act independently, impartially and in the public interest'. The ACT legislation also seeks to prevent conflict of interests by stipulating that ' $[t]$ he inspector must not (a) have

193 The Commonwealth Ombudsman reports that the Ombudsman's statutory appointment meets 'the OPCAT requirement for independence', the office has its own budget and can publish reports: Commonwealth Ombudsman, Commonwealth Ombudsman Implementation of the Optional Protocol to the Convention Against Torture and Other Cruel, Inhuman or Degrading Treatment or Punishment (OPCAT) Baseline Assessment of Australia's OPCAT Readiness Report No. 3/2019 (September 2019) 21. Groves details the mechanisms that make Ombudsmen independent as follows: 'Ombudsmen are normally granted secure tenure, and may only be removed by a vote of Parliament. They are also granted immunity from civil liability for acts and conduct made in good faith in the discharge of their duties. Importantly, Ombudsmen are not subject to any form of ministerial direction': Groves, above n 138, 184. The Victorian Ombudsman's independence stems from the Constitution: Victorian Ombudsman, above n 6, 37.

194 McMillan, above n 177, 449. See illustrations provided by McMillan: at 449-52.

195 Ibid 441.

196 Commonwealth Ombudsman, above n 193.

197 Ibid 21 (ACT), 22 (NSW), 27 (Tasmania), 29 (Western Australia). 
paid employment that is inconsistent with the inspector's functions; or (b) engage in any unpaid activity that is inconsistent with the inspector's functions. ${ }^{198}$

However, there are also prison monitoring bodies that lack the requisite independence. For example, the Justice Assurance and Review Office (JARO) in Victoria and the Chief Inspector in Queensland are both located within the relevant government departments ${ }^{199}$ and the Commonwealth Ombudsman's baseline assessment has found both to lack the functional independence required by the OPCAT. ${ }^{200}$ Inspection reports conducted by these bodies are not made publicly available. A summary of the JARO's work is provided in the Victorian Department of Justice annual reports, ${ }^{201}$ and the Queensland Chief Inspector provides a report to the DirectorGeneral of Corrective Services. ${ }^{202}$

The Queensland Government reportedly plans to establish an independent inspectorate with responsibility for both adult and juvenile facilities. ${ }^{203}$ There have been a number of calls to establish an independent prison inspectorate in Victoria due to concerns about the Office of Correctional Services Review's (OCSR's) (JARO's predecessor) lack of independence and transparency. ${ }^{204}$ For example, the Victorian Ombudsman has made such recommendations, noting that ' $[t]$ he Victorian community should have confidence that the prison system is subject to independent, robust and transparent oversight. By any measure,

198 Inspector of Correctional Services Act 2017 (ACT) s 11. In relation to OICS's independence see Richard Harding and Neil Morgan, 'OPCAT in the Asia-Pacific and Australasia' (2010) 6(2) Essex Human Rights Review 99, 122.

199 Department of Justice and Regulation in Victoria and Queensland Corrective Services. Harding and Morgan have noted that the Queensland Inspectorate lacks 'functional independence': AHRC OPCAT report, above n 140, 27.

200 Commonwealth Ombudsman, above n 193, 24 (Queensland), 28 (Victoria).

201 See, eg, Department of Justice and Regulation, Annual Report 2017-18 (2018) 205-7.

202 Corrective Services Act 2006 (Qld) s 305. The Queensland Inspector has made some inspection reports from 2009-2013 available online: Queensland Government Queensland Corrective Services, Healthy Prison Report <https://corrections.qld.gov.au/documents/reviews-and-reports/healthy-prisonreport/>.

203 Commonwealth Ombudsman, above n 193, 25.

204 The Office of Correctional Services Review became the Justice Assurance and Review Office when the office was given responsibility for youth justice in April 2017: Department of Justice and Regulation, above n 201, 205. 
the OCSR does not achieve any of these objectives'. ${ }^{205}$ The Human Rights Law Centre, Law Institute of Victoria and Jesuit Social Services have echoed this sentiment. ${ }^{206}$

\section{Expertise}

Article 18(2) of the OPCAT specifies that 'State Parties shall take the necessary measures to ensure that the experts of the national preventive mechanism have the required capabilities and professional knowledge. They shall strive for a gender balance and the adequate representation of ethnic and minority groups in the country'. Part of the reason for this requirement is that the OPCAT applies to varied places of detention. It may, for example, be appropriate to have personnel with military expertise when visiting military facilities and people with psychiatric expertise when visiting psychiatric institutions. ${ }^{207}$

Legislation establishing existing monitoring bodies in Australia is vague about the type of expertise required and, therefore, is unlikely to satisfy the OPCAT requirements. The Inspector of Custodial Services Act 2003 (WA) provides that an 'appropriately qualified person' should fill the position of Inspector, ${ }^{208}$ and the Inspector of Correctional Services Act 2017 (ACT) notes that 'the Executive must not appoint a person as the inspector unless satisfied that the person has the experience or expertise necessary to exercise the inspector's functions'. ${ }^{209}$ The NSW and Tasmanian legislation do not specify any particular qualifications. ${ }^{210}$

205 Victorian Ombudsman, above n 143, 135; Victorian Ombudsman, The Death of Mr Carl Williams at HM Barwon Prison - Investigation into Corrections Victoria (2012) 146.

206 ABC News Radio, 'Calls for Independent Prisons Monitor to Address Crisis in Vic System', The World Today, transcript of interview 26 November 2013, <http://www.abc.net.au/worldtoday/ content/2013/s3899083.htm>; Law Institute, 'Calls for Independent Prisons Inspection Body' (2008) 82(6) Law Institute Journal 22; Jesuit Social Services, All Alone. Young Adults in the Victorian Justice System (2018) 38-9.

207 Rachel Murray et al, The Optional Protocol to the UN Convention Against Torture (Oxford University Press, 2011) 135.

208 Inspector of Custodial Services Act 2003 (WA) s 6.

209 Inspector of Correctional Services Act 2017 (ACT) s 9(3).

210 Section 4(1) of the Inspector of Custodial Services Act 2012 (NSW) provides that ' $\mathrm{t}$ ] $\mathrm{he}$ Governor may appoint an Inspector of Custodial Services'. Section 5 of the Custodial Inspector Act 2016 (Tas) provides that 'The Governor may appoint a person as Custodial Inspector'. 
Only one jurisdiction-the ACT-stipulates that there should be the transparent selection process detailed above required to achieve independence of personnel. The Act provides that ' $\mathrm{t}$ ] he appointment must be made in accordance with an open and accountable selection process..$^{211}$

In relation to 'ethnic and minority groups' representation required by OPCAT, it will be essential for organisations inspecting prisons in Australia to have Indigenous representation in light of the proportion of the prison population that is Indigenous (as documented in Chapter 1). This point was highlighted by the Victorian Ombudsman in their OPCAT-compliant inspection of the Dame Phyllis Frost Centre in Victoria, despite the fact that it was not possible for the inspection team to include an Aboriginal person for that particular inspection. ${ }^{212}$ The team instead sought advice from several Aboriginal people and organisations. ${ }^{213}$

Given the high proportion of people with cognitive disability in prisons (discussed in Chapter 1), consideration should also be given to ensuring Australian organisations that form part of the NPM are what Weller has termed 'disability aware', which may include having people with lived experience form part of monitoring teams. ${ }^{214}$

Where inspections are being carried out by a dedicated prison inspectorate, it is likely that staff will develop suitable expertise. This may also be the case in the JARO, which is dedicated to prison monitoring. Suitable attention will need to be given to the requirements for gender balance and diversity.

Appropriate expertise is less likely to be found in non-specialist monitoring bodies, such as generalist Ombudsmen that cover a range of public service organisations and, therefore, are unlikely to have particular expertise relating to prisons. This is particularly the case in smaller jurisdictions, such as the Northern Territory and Queensland (discussed below), and when inspections are rare.

211 Inspector of Correctional Services Act 2017 (ACT) s 9(2).

212 Victorian Ombudsman, above n 6, 46.

213 Ibid 48.

214 Penelope Weller, 'OPCAT Monitoring and the Convention on the Rights of Persons with Disabilities' (2019) 25(1) Australian Journal of Human Rights 130, 143. 


\section{Adequate Resourcing}

Article 18(3) of the OPCAT stipulates that 'State Parties undertake to make available the necessary resources for the functioning of the national preventive mechanisms'. This is essential for the independence of the organisation. This connection is provided for by Principle 2 of the Principles Relating to the Status of National Institutions (The Paris Principles) as follows:

The national institution shall have an infrastructure which is suited to the smooth conduct of its activities, in particular adequate funding. The purpose of this funding should be to enable it to have its own staff and premises, in order to be independent of the Government and not subject to financial control which might affect its independence.

The reality in Australia is that while monitoring bodies may have the statutory responsibility to monitor prison conditions, they lack the resources to do so in practice. A survey of organisations responsible for monitoring closed environments across Australia found that 59 per cent considered their current resources to be 'inadequate'. ${ }^{215}$

The ACT Human Rights Commission's submission to the AHRC consultation on OPCAT noted that:

while several entities are empowered to address systemic issues through various audit powers, own motion powers, annual reporting processes, or informal engagement with authorities, these bodies are not sufficiently resourced to use these powers with the regularity and consistency required of a NPM. ${ }^{216}$

The Commission has previously noted that lack of resources has specifically prevented them from conducting a comprehensive audit of the AMC, and they instead opted to audit the treatment of women only. ${ }^{217}$

215 Working Paper 3, above n 136, 22.

216 ACT Human Rights Commission, Response to the Australian Human Rights Commission's May 2017 'OPCAT in Australia Consultation Paper' (21 July 2017) 3.

217 The report states 'there are not sufficient resources to conduct a comprehensive Human Rights Audit of all detainees' conditions of detention': ACT Human Rights Commission, Annual Report 2012-2013 (2013) 7. See also ACT Human Rights Commission, Annual Report 2011/12 (2012) 13. The audit of the treatment of women is by the Australian Capital Territory Human Rights Commission, above n 130. The report made 61 recommendations about ways to improve the treatment of, and services provided to, women in the Alexander Maconochie Centre. 
The OICS has also expressed concern that budget cuts are restricting the office's ability to carry out their statutory functions. New prisons have been opened, yet the OICS's budget has been cut. The most recent annual report noted that 'budget constraints make it increasingly difficult for us to meet our statutory responsibilities and to provide advice that reduces risk and maximises opportunities'. ${ }^{218}$

State and territory governments around Australia are implementing 'tough on crime' policies that are causing prison populations to increase (as demonstrated by the statistics outlined in Chapter 1 ). This is very expensive, given that it costs on average $\$ 391.18$ per day to keep someone in prison. ${ }^{219}$ The resources required for independent external monitoring are, by comparison, a fraction of this. For example, the OICS budget is 'just 0.4 of one per cent of the corrections budget' in WA. ${ }^{220}$ This is comparable with other jurisdictions with established OPCAT-compliant inspectorates. Harding writes that:

the Correctional Investigator Canada, an OPCAT-compliant inspectorate that oversights the federal prison system, costs about 0.15 of $1 \%$ of the cost of the operational Department. The UK Inspector of Prisons comes in at about 0.4 of $1 \%$ of the cost of carrying out the inspect[ion] activities. ${ }^{221}$

It is not unreasonable to expect governments to increase budgetary allocations for external oversight as they increase their prison populations. Allocating resources to monitoring should be seen as an investment. Preventing human rights abuses has a value that cannot be quantified in economic terms for the lives of imprisoned people. However, even if this is set aside, preventing human rights abuses can save governments money by avoiding litigation and compensation pay-outs when violations do occur. For example, following the death of Mr Ward (discussed further below), the WA Government paid his family members $\$ 3.2$ million in compensation. ${ }^{222}$ In the Tasmanian case of Pickett $v$ State of Tasmania, the government was ordered to pay $\$ 30,000$ in legal costs. ${ }^{223}$

218 OICS, Annual Report 2017-18 (2018) 13.

219 Australian Institute of Criminology, How Much Does Prison Really Cost? Comparing the Costs of Imprisonment with Community Corrections (Research Report No 5, 2018) x.

220 OICS, above n 218, 13.

221 Harding, above n 2, 18.

222 Chalpat Sonti, 'Multimillion-Dollar Payout to Mr Ward's Family After Prison Van Death', WA News (Western Australia), 29 July 2010.

223 Pickett $v$ The State of Tasmania [2011] TASSC 907 (20 April 2011). 
Allocating money to OPCAT-compliant monitoring may avoid the need for a Royal Commission, ${ }^{224}$ coronial inquest or parliamentary committee inquiry, all of which are very expensive. For example, the 2016-2017 Royal Commission into the Protection and Detention of Children in the Northern Territory which was required to investigate problems in two juvenile detention centres (as well as child protection) had a budget of $\$ 54$ million (paid for jointly by the federal and Northern Territory governments), plus the Northern Territory reportedly spent a further $\$ 16$ million for legal and staffing costs. ${ }^{25}$ By contrast, the Victorian Ombudsman's OPCAT-compliant inspection of the Dame Phyllis Frost Centre in Victoria cost $\$ 105,000 .{ }^{226}$ Given an OPCAT inspection has the aim of preventing human rights abuses of multiple imprisoned people, this is by any definition better value for money.

\section{Regular Visits to Ensure Protection From Torture and Other Cruel, Inhuman or Degrading Treatment or Punishment}

Article 19(a) of the OPCAT requires that 'at a minimum' NPMS should have the power to 'regularly examine the treatment of the persons deprived of their liberty ... with a view to strengthening, if necessary, their protection against torture and other cruel, inhuman or degrading treatment or punishment'. There are two elements to this criterion. The first concerns the regularity of visits. The second concerns the purpose of the visits, which is to protect against torture and other cruel, inhuman or degrading treatment or punishment (TCID).

\section{Regularity}

Deitch has made the following observations about the role of regular monitoring: 
Regular monitoring helps keep the quality of correctional services high, because the staff's knowledge that an inspector could arrive at any time acts as a means of informal control over staff behavior. In other words, it 'keeps staff on their toes' and helps them avoid complacency, even when everything is going well. ${ }^{227}$

Regular visits should be required by legislation in the way that threeyearly visits are specified in the WA legislation establishing the OICS and the Tasmanian legislation establishing the TOCI. Five-yearly visits are specified in the equivalent NSW legislation (as previously detailed in this chapter under 'Current Monitoring System in Australia'). While there is no inspection interval specified in the ACT legislation, the ACT Inspector has conducted one inspection, produced one thematic review (on the treatment of remandees) and reported on five critical incidents in the first two years of operation. ${ }^{228}$

In the absence of legislation requiring regular visits, inspections occur on an ad hoc basis. This is particularly the case in jurisdictions without inspectorates. In a survey conducted of oversight agencies with responsibilities for closed environments in Australia, ${ }^{229}$ it was found that the power to conduct systemic reviews was used 'rarely' by 48 per cent of organisations who had the power. Similarly, the power to conduct thematic reviews was used 'rarely' by 46 per cent and never by a further 12 per cent. Moreover, the power to conduct own motion investigations was used 'rarely' in 57 per cent of cases and never in a further four per cent. ${ }^{230}$ These results indicate a widespread absence of regular inspection by monitoring bodies nationally.

Ombudsmen in some jurisdictions do opt to investigate prisons regularly using their 'own motion' powers. The South Australian Ombudsman is probably the most active prison inspector in Australia other than the designated prison inspectors that have a statutory mandate to inspect prisons at set intervals. The South Australian Ombudsman has conducted prison investigations in 2010 and 2011; two in 2012; 2013 and 2014;

227 Michele Deitch, 'Distinguishing the Various Functions of Effective Prison Oversight' (2010) 30 Pace Law Review 1438, 1443. For a discussion of how 'regular' has been interpreted by NPMs in Europe see Nick Hardwick and Rachel Murray, 'Regularity of OPCAT Visits by NPMs in Europe' (2019) 25(1) Australian Journal of Human Rights 66.

228 ACT Inspector of Correctional Services, Our Reports <https:/www.ics.act.gov.au/reports-andpublications>.

229 That is, organisations including, but not limited to, prisons.

230 Working Paper 3, above n 136, 12. 
three in 2016 and 2017; and two in 2018 and 2019. ${ }^{231}$ The Victorian Ombudsman is also dedicated to prison inspections and has been conducting prison-focused investigations with increasing frequency. ${ }^{232}$ This is entirely at the initiative of the particular Ombudsmen.

The situation is different in other jurisdictions. It is particularly concerning that investigations have not been carried out for years at a time in the Northern Territory, given that the Northern Territory has the fastest growing prison population in the country (as discussed in Chapter 1) and does not have a prison inspectorate. In the Northern Territory, the Ombudsman has not investigated male prison conditions since 2008. It has produced two reports about women's imprisonment in that timeframe (in 2008 and 2017). ${ }^{233}$ The Commonwealth Ombudsman has reported that there is not a fully independent, regular preventive prison inspection system' in the Northern Territory and that the Ombudsman's inspections 'occur on an ad hoc basis' ${ }^{234}$

\footnotetext{
231 All of the following reports are by the Ombudsman South Australia: Department for Correctional Services - Port Augusta Prison Disturbance (2010), Department for Correctional Services - Prisoner Amenities Levy (2011), Department for Correctional Services - Continuing Separation of a Prisoner (2012), Ombudsman Investigation into the Department of Correctional Services in Relation to the Restraining and Shackling of Prisoners in Hospitals (2012), Department for Correctional Services - Treatment of a Prisoner (2013), Department for Correctional Services - Restraint of a Prisoner (2014), Department for Correctional Services - Shackling of a Prisoner in Hospital (2016), Department for Correctional Services Unreasonable Shackling of a Prisoner in Hospital (2016), Department for Correctional Services - Prohibition of Correspondence (2016), Department for Correctional Services - Unjust and Oppressive Separation of a Prisoner (2017), Department for Correctional Services - Failure to Ensure that a Prisoner Understood the Induction Process (2017), Department for Correctional Services - Failure to Induct Prisoner (2017), Department for Correctional Services-Failure to Amend Record of Gender Media Release (2018), Department for Correctional Services - Handling of a Prisoner's Diabetes (2018), Department for Correctional Services - Handling of a Physical Altercation (2019) and Restraint of Prisoner During Hospitalisation - Compliance with Standard Operating Procedures in Relation to Checking of Restraints (2019).

232 The Victorian Ombudsman has produced the following reports between 2005 and 2018: Investigation into the Handling, Storage and Transfer of Prisoner Property in Victorian Prisons (2005); Conditions for Persons in Custody (2006) (produced in conjunction with the Office of Police Integrity); Investigation into Contraband Entering a Prison and Related Issues (2008); Investigation into Prisoner Access to Health Care (2011); The Death of Mr Carl Williams at HM Barwon Prison - Investigation into Corrections Victoria (2012); Investigation into Children Transferred from the Youth Justice System to the Adult Prison System (2013); Investigation into Deaths and Harms in Custody (2014); Investigation into the Rehabilitation and Reintegration of Prisoners in Victoria (2015); Implementing OPCAT in Victoria: Report and Inspection of the Dame Phyllis Frost Centre (2017); and Investigation into the Imprisonment of a Woman Found Unfit to Stand Trial (2018).

233 Ombudsman for the Northern Territory, Women in Prison Northern Territory. Report of the Investigation into Complaints from Women Prisoners at Darwin Correctional Centre (2008); Ombudsman NT, Ombudsman NT Investigation Report. Women in Prison II - Alice Springs Women's Correctional Facility (2017).
}

234 Commonwealth Ombudsman, above n 193, 23-4. 
There is also an absence of prisons monitoring in Queensland-another jurisdiction without a prison inspectorate. The Queensland Ombudsman has only prepared one report about male prisons and two reports about women's prisons since 2006. ${ }^{235}$ The Anti-Discrimination Commission has prepared two reports about women's prisons. ${ }^{236}$

Based on this overview, 'regular', or at least not infrequent, inspections are carried out in the four jurisdictions with inspectorates (WA, NSW, ACT and Tasmania) and the two jurisdictions with proactive Ombudsmen (South Australia and Victoria). This leaves the Northern Territory and Queensland with an absence of regular preventive monitoring. This should be addressed when the NPM is operational, provided the NPM satisfies the OPCAT criterion of regular inspections.

\section{Criteria Targeted at Protection}

The importance of the standards for monitoring being both human rights based and preventive focused should not be underestimated. The way this should operate in practice is articulated by Lawson:

Publication of the basic expectations ... can serve to inform those responsible for places of detention of how relevant monitoring bodies consider that detainees 'ought to be treated'. It can thus help to drive up standards - a process underpinned by inspection visits and dialogue. ${ }^{237}$

Compliance with this criterion is mixed throughout Australia. All jurisdictions with prison inspectorates have published criteria or standards. While the Victorian Ombudsman carries out their prison inspections by reference to the Charter and used TCID as the framework for the OPCAT inspection in 2017, this is not the same as having standards for monitoring. ${ }^{238}$

235 Queensland Ombudsman, The Classification and Movement of Prisoners Report. An Investigation of Queensland Corrective Services' Process for the Classification, Placement and Transfer of Prisoners (2009); Queensland Ombudsman, Strip Searching of Female Prisoners Report (2014); Queensland Ombudsman, Overcrowding at Brisbane Women's Correctional Centre Report (2016).

236 Anti-Discrimination Commission Queensland, Women in Prison 2019, above n 130; AntiDiscrimination Commission Queensland, Women in Prison, above n 130. NSW Ombudsman investigation reports about prisons may also be described as rare. The last report by this office was in 2012: Ombudsman New South Wales, Managing Use of Force in Prisons: The Need for Better Policy and Practice (2012). This may be due to the appointment of the Inspector of Custodial Services in 2013. 237 Anna Lawson, 'Disability, Equality, Reasonable Accommodation and the Avoidance of IllTreatment in Places of Detention: The Role of Supranational Monitoring and Inspection Bodies' (2012) 16(6) The International Journal of Human Rights 845, 860 (emphasis added).

238 The South Australian Ombudsman also frequently refers to international human rights law in reports. See, eg, the finding that 'the complainant was kept separated from other prisoners for a period well in excess of the maximum period identified by the Special Rapporteur and established by the Mandela Rules': Ombudsman South Australia, Department for Correctional Services - Unjust and 
The OICS in WA publishes three sets of detailed Codes of Inspectionone for adults, one for Indigenous imprisoned people and one for young people in detention. ${ }^{239} \mathrm{In}$ an interview, it has been suggested that the OICS standards are 'based' on human rights, and that 'the ... absence of specific human rights legislation in WA has not hindered the work of this office'. ${ }^{240}$ The code makes some specific references to cruel treatment and also refers to the relevant 1955 UN Standard Minimum Rules for the Treatment of Prisoners that preceded the Mandela Rules (because the Mandela Rules were released after the inspection standards) throughout. ${ }^{241}$

The NSW inspection standards, published in 2014, are organised around five categories: (1) custody, (2) care and wellbeing, (3) rehabilitation, (4) reparation and (5) resources and systems. ${ }^{242}$ There is explicit reference to the human rights foundation of the NSW inspection standards that is not in evidence in the WA Code. The introduction describes the standards as 'founded on an approach which is considerably broader than an inevitably limited human rights-based approach' and ' $t \mathrm{t}]$ he basis of the Inspection Standards lies in the principles of independent inspection, accountability, prevention, purposeful and rehabilitative imprisonment, and the protection of human rights. ${ }^{243}$

The Tasmanian legislation requires the TOCI 'to prepare and publish guidelines and standards in relation to the conduct of inspections', which the TOCI did in November 2018. ${ }^{244}$ The Tasmanian standards note that they 'draw significantly on the NSW standards, and were developed with the assistance of the WA OICS'. ${ }^{245}$ They are organised under similar headings to the NSW standards, except that 'rehabilitation and reintegration' is one heading and there is no separate category for reparation. The Tasmanian standards also explicitly refer to the protection of human rights, noting, '[t]he observance of human rights is integral

239 OICS, How We Inspect <http://www.oics.wa.gov.au/how-we-inspect/>.

240 Working Paper 3, above n 136, 36.

241 For example, in noting that segregation may constitute 'cruel and unusual punishment': OICS, Code of Inspection Standards for Adult Custodial Services, Version 1 (19 April 2007) 32. See also pages $6,7,32$.

242 NSW Inspector of Custodial Services, Inspection Standards for Adult Custodial Services in New South Wales (2014).

243 Ibid 5-6.

244 Custodial Inspector Act 2016 (Tas) s 6(1)(c); Office of the Custodial Inspector Tasmania, Inspection Standards for Adult Custodial Services in Tasmania (2018). The office has separate inspection standards' for young people, published in July 2018.

245 Ibid Foreword. 
to good prison management and the most effective and safest way of managing prisons. A prisoner's fundamental human rights are not forfeited because of their imprisonment and are limited only in so far as is necessitated by the fact of imprisonment'. ${ }^{246}$

Both the NSW and Tasmanian standards make numerous references to human rights, the 1955 UN Standard Minimum Rules for the Treatment of Prisoners that preceded the Mandela Rules (because the Mandela Rules were released after the inspection standards, so the standards need to be updated to reflect changes to these Rules), as well as the UN Rules for the Treatment of Women Prisoners and Non-Custodial Measures for Women Offenders ('the Bangkok Rules'). ${ }^{247}$ Both of these standards include provisions that are both preventive in focus and human rights compliant, such as:

Staff should be consistently fair and firm in their dealings with inmates and model respectful relations at all times. ${ }^{248}$

Prolonged solitary confinement, corporal punishment, punishment by placement in a dark cell, reduction of diet, sensory deprivation and all cruel, inhumane or degrading punishments must not be used. ${ }^{249}$

Instruments of restraint should be:

- used only where the restraint of an inmate is strictly necessary to maintain the security of the inmate or prevent injury to any person;

- of the least restrictive type appropriate;

- applied for the minimum time necessary to control the inmate; and

- removed during medical tests and procedures, provided this meets security and management requirements. ${ }^{250}$

246 Ibid.

247 United Nations Rules for the Treatment of Women Prisoners and Non-Custodial Measures for Women Offenders, UN Doc A/RES/65/229 (adopted by the General Assembly on 21 December 2010) ('the Bangkok Rules').

248 NSW Inspector of Custodial Services, above n 242, 57, standard 67.1; Office of the Custodial Inspector Tasmania, above n 244, 53, standard 66.1.

249 NSW Inspector of Custodial Services, above n 242, 45, standard 52.5. The wording of the Tasmanian standard is identical except for the final sentence that says 'should not be used' (rather than 'must not'): Office of the Custodial Inspector Tasmania, above n 244, 41, standard 53.4.

250 NSW Inspector of Custodial Services, above n 242, 47, standard 55.1; Office of the Custodial Inspector Tasmania, above n 244, 44, standard 56.1. 
The ACT Standards are the most recent to have been published (in 2019) and they specifically refer to both the Mandela Rules and OPCAT:

These ACT Standards were prepared with the OPCAT's preventive approach to oversight in mind to provide a relevant standard against which this oversight of adult corrections can occur once the relevant provisions of the OPCAT are operational in the ACT. ${ }^{251}$

Similarly to the inspection criteria used by HMIP (known as Expectations), the ACT Standards are based on the four pillars of the 'healthy prison' test by the World Health Organization:

- Safety: detainees, particularly the most vulnerable, are held safely and staff and visitors feel and are safe;

- Respect: all persons are treated with respect for their human dignity;

- Purposeful activity: detainees engage in activity that is likely to benefit them;

- Rehabilitation and preparation for release: detainees are supported to connect with their family and the community; supported to rehabilitate; and prepared for release back into the community. ${ }^{252}$

For each pillar there are standards, indicators and evidence detailed for the purposes of inspections. This led to an extremely comprehensive inspection of the AMC in late 2019, resulting in a 164-page report. ${ }^{253}$ The ACT Standards provide significantly more detail on some of the matters referred to above in relation to the NSW and Tasmanian standards. For example, there is more detailed guidance about use of restraints, including absolute prohibition in certain circumstances. Restraints are 'never' to be used 'for disciplinary action' (indicator 14.3), 'on women during labour, childbirth and immediately after childbirth' (indicator 14.6), or if they are 'inherently painful or degrading' (indicator 14.2). When they are used, they are 'only applied by staff who are appropriately trained' (indicator 14.7) and use is to be 'always in accordance with law, appropriately recorded, used in the least restrictive manner possible, and in a way that is mindful of detainee dignity' (indicator 14.1)..$^{254}$

251 ACT Inspector of Correctional Services, ACT Standards for Adult Correctional Services (2019) 7.

252 Ibid 5 (emphasis in original).

253 ACT Inspector of Correctional Services, Report of a Review of a Correctional Centre by the ACT Inspector of Correctional Services: Healthy Prison Review of the Alexander Maconochie Centre (2019).

254 Ibid 23. 
The ACT inspection standards offer the best example of human rightsbased prison inspection criteria for prison monitoring in Australia. They are aligned with both the Mandela Rules and the preventive focus of the OPCAT and have drawn on the experience of HMIP that was established in 1982 and has been using the 'healthy prison' test as a basis for inspections for over a decade. ${ }^{255}$

\section{Functions and Powers}

Article 20 of the OPCAT specifies that NPMs should have the power to choose the places of detention they visit, full access to such places, and private interviews with people who are detained and other relevant individuals. These powers are important for the monitoring body to be able to objectively assess the daily practices in the individual prison. This reflects the role envisaged for NPMs by the OPCAT. They are intended to 'provide local and regular scrutiny of the day-to-day reality of detention and of the risk of ill-treatment than [sic] would otherwise be possible'. ${ }^{256}$

Most Australian monitoring organisations have adequate functions and powers, so this is a criterion against which they perform well. ${ }^{257}$ As previously outlined in this chapter, the prison inspectorates have broad powers provided for by legislation-in particular, the ACT Inspector, who is required to review critical incidents. Other relevant legislative provisions make it an offence to obstruct the activities of the Inspectors. ${ }^{258}$ Additionally, in NSW and the ACT, it is an offence to seek retribution against a person who has provided information to the Inspector as part of their investigations. For example, s 20 of the Inspector of Custodial Services Act 2012 (NSW) provides:

255 The expectations based on the 'healthy prison' were well established by 2006: Anne Owers, 'The Protection of Prisoners' Rights in England and Wales' (2006) 12 European Journal on Criminal Policy and Research 85, 88.

256 Statement by Mr Malcolm Evans, Chairperson of the SPT, 23 October 2012, cited by Steinerte, above n 178,6 .

257 A summary of the powers of oversight bodies surveyed for the purposes of the Australian Research Council project 'Applying Human Rights in Closed Environments: A Strategic Framework for Managing Compliance' is provided in Working Paper 3, above n 136, 11.

258 See, eg, Inspector of Custodial Services Act 2012 (NSW) s 19; Inspector of Custodial Services Act 2003 (WA) s 32; Custodial Inspector Act 2016 (Tas) ss 9, 25. 
A person must not take or threaten to take detrimental action against another person because that other person or any other person provides, or proposes to provide, information, documents or evidence to the Inspector or a member of staff of the Inspector in the exercise of functions under this Act. ${ }^{259}$

Ombudsman legislation ordinarily provides the power to enter premises ${ }^{260}$ and to have people appear before them voluntarily and involuntarily. ${ }^{261}$ It is also typically an offence to obstruct Ombudsman investigations. ${ }^{262}$ These legislative provisions can be seen to support independence of personnel, as discussed above.

The AHRC is also consulting stakeholders on how suitable legislation might be drafted to give suitable functions and powers to all organisations that comprise the NPM. Their 2018 consultation paper posed the question, ' $[\mathrm{w}]$ hat are the core principles that need to be set out in relevant legislation to ensure that each body fulfilling the NPM function has unfettered, unrestricted access to places of detention in accordance with OPCAT?'263

This legislation could certainly draw on the legislation establishing prison inspectorates in WA, NSW, Tasmania and the ACT. The ACT is arguably the most OPCAT-compliant legislation, which is unsurprising given it is the most recent inspectorate Act passed in Australia and the $H R A$ requires that all legislation be accompanied by a statement of compatibility with the $H R A$ when it is introduced into Parliament. ${ }^{264}$ One addition to the ACT legislation that is required in jurisdictions with more than one prison is a requirement for regular inspections, such as the requirement for three-yearly inspections contained in the WA and Tasmanian Acts. ${ }^{265}$

259 See also Inspector of Correctional Services 2017 (ACT) s 26.

260 Ombudsman Act 1974 (NSW) s 20; Ombudsman Act 2001 (Qld) s 34; Ombudsman Act 1972 (SA) s 23; Ombudsman Act 1978 (Tas) s 25; Ombudsman Act 1973 (Vic) s 21.

261 Ombudsman Act 1974 (NSW) s 19; Ombudsman Act 2001 (Qld) ss 25, 29, 36; Ombudsman Act 1978 (Tas) s 24.

262 Ombudsman Act 1972 (SA) s 24; Ombudsman Act 1978 (Tas) s 27; Ombudsman Act 1973 (Vic) s 22 .

263 Australian Human Rights Commission, above n 4, 7 (consultation question 4).

264 HRA s 37.

265 Inspector of Custodial Services Act 2012 (WA) s 19; Custodial Inspector Act 2016 (Tas) s 6(1). This is preferable to the five-yearly intervals prescribed by the NSW Act because this is too long between inspections (Inspector of Custodial Services Act 2012 (NSW) s 6). 


\section{Implementation of Recommendations}

It is critical for the independence of monitoring bodies that they be separate from government. However, this means that they are not empowered to implement or enforce their recommendations. Acceptance and implementation of recommendations remains the responsibility of the relevant government. ${ }^{266}$ The main mechanism Australian external monitoring bodies have for encouraging compliance with their recommendations is publication of their reports, which may attract media attention. ${ }^{267}$

Articles 19(b) and 22 of the OPCAT are relevant to this final criterion. Article 19(b) provides that NPMs have the power to 'make recommendations to the relevant authorities with the aim of improving the treatment and the conditions of the persons deprived of liberty'. Article 22 provides that 'authorities of the State Party concerned shall examine the recommendations of the national preventive mechanism and enter into a dialogue with it on possible implementation measures'.

Failure of governments to implement the recommendations of monitoring organisations is arguably the biggest weakness of the external monitoring landscape in Australia. There are numerous examples of this failure across Australia, but four of significance will suffice to illustrate the point here. ${ }^{268}$

The first example is the widespread failure of jurisdictions to respond to the recommendations made by the RCIADIC. The UN Special Rapporteur for Indigenous People noted in 2017 that many of the recommendations of the RCIADIC have not been implemented, drawing particular attention to the failure to address the growth in Indigenous over-representation, address deaths in custody and implement 'custody notification services'. ${ }^{269}$

266 Murray et al, above n 207, 133.

267 For example, "Woman Gave Birth Alone in Perth Prison Cell in "Degrading" Conditions, Report Finds', The Guardian (Australia), 12 December 2018; Calla Wahlquist, 'Tasmanian Prisons Report Uncovers "Degrading” Conditions - and One Plague of Rabbits', The Guardian (Australia), 1 December 2018; Richard Willingham, 'Prison Death Risks Rising: Ombudsman George Brouwer Warns on Overcrowding', The Age (Victoria), 26 March 2014; Michael Owen, 'Shackling Prisoners "is Illegal", The Australian (Australia), 5 September 2012.

268 Other examples are provided elsewhere in this book, such as the South Australian Government's refusal to change the policy relating to shackling of imprisoned people receiving medical treatment (including end-of-life care and women in labour) that has been heavily criticised by the South Australian Ombudsman (see Chapter 7).

269 Human Rights Council, above n 170, 12-13. 
The Northern Territory's response is relevant here, given this jurisdiction has the highest proportion of the prison population that is Indigenous in Australia. ${ }^{270}$ In a 2012 update on the implementation of recommendations, Bartels highlights that the Northern Territory has done little in response to the recommendations. ${ }^{271}$ There is also the failure to remove hanging points in cells in a number of jurisdictions, again including the Northern Territory, as repeatedly raised in coronial inquests. A Coroner noted in 2017, 'it beggars belief that a prison designed and constructed in the 21st century has such classic hanging points with no mitigation of that risk'. ${ }^{272}$ In 2014, it was found that 38 per cent of Victorian prison cells still have hanging points $\mathrm{s}^{273}$ and the South Australian Coroner has repeatedly raised concerns about hanging points in that jurisdiction. ${ }^{274}$

The second example is the death of Mr Ward in WA (mentioned in relation to the coronial inquest). This could have been prevented if the WA Government had followed earlier recommendations of the OICS. Mr Ward, an Aboriginal elder, died in the back of a prison transport van while being transported $360 \mathrm{~km}$ in WA to face minor charges in court-a journey taking almost four hours. Mr Ward died of heatstroke because of the extremely hot temperature in the van, where no air-conditioning was provided. The temperature in the van was found by the Coroner to be over 50 degrees Celsius and Mr Ward had third degree burns on his body where his skin had come into contact with the metal floor. ${ }^{275}$ The two drivers of the van were criticised by the Coroner for, among other things, failing to check that the air-conditioning was working in the back of the van before setting out, failing to provide Mr Ward with cold drinking water during the journey (he was only provided with a $600 \mathrm{ml}$ bottle of water at the start of the journey), and not stopping to check Mr Ward's welfare throughout the entire journey, or to see if he needed to use a toilet. ${ }^{276}$

27083.4 per cent: Australian Bureau of Statistics, Prisoners in Australia 2019 (5 December 2019) Table 14.

271 Lorana Bartels, 'Twenty Years On: Indigenous Deaths in Police Custody and Lessons from the Frontline' in Isabelle Bartkowiak-Théron and Nicole Asquith (eds), Policing Vulnerabilities (Federation Press, 2012) 190-1.

272 Inquest into the Death of Roy Melbourne [2017] NTLC 017 [47]. See also Inquest into the Death of Vernon Bonson [2018] NTLC 006; Inquest into the Death of Bird [2011] NTMC 050.

273 Victorian Ombudsman, above n 143, 6.

274 Elizabeth Grant, 'Approaches to the Design and Provision of Prison Accommodation and Facilities for Australian Indigenous Prisoners after the Royal Commission into Aboriginal Deaths in Custody' (2014) 17(1) Australian Indigenous Law Review 47, 48.

275 Hope, above n 161, 34, 8-9.

276 Ibid 63, 65, 82-3. 
The OICS had provided two reports to the WA Government (in 2004 and 2007) containing advice about the dangers of using the outdated prison transport vans in operation in WA. ${ }^{277}$ The OICS had specifically recommended significant enhancements, including '[r] obust climate control for staff and passengers, adjustable in each zone'. ${ }^{278}$ The Coroner concluded, '[i] $\mathrm{n}$ my view all of the above observations made by the OICS were accurate and should have been acted upon as a matter of urgency'. ${ }^{279}$

The WA Government has made some significant changes to transport arrangements and services since the death of $\mathrm{Mr}$ Ward and the subsequent coronial inquest. These include the use of planes and coaches for transport over long distances; use of alternatives to travelling to court, such as audio-visual links; engaging a different service provider to operate prison transport services; and greater emphasis on both the duty of care owed by staff when transporting imprisoned people and appropriate training for staff. ${ }^{280}$

A third example is the problems in the Risdon prison in Tasmania. Successive reports have highlighted serious concerns with prison conditions and management, including failure to prevent self-harm and suicide of people in prison. ${ }^{281}$ In 2001, the Tasmanian Ombudsman observed, '[n]o prison is a pleasant place, but the Risdon Prison is a particularly unpleasant place. It is bleak, cold and grey and, even if a

277 OICS, Report of an Announced Inspection of Adult Prisoner Transport Services (2004); OICS, Thematic Review of Custodial Transport Services in Western Australia (2007).

278 See OICS, Thematic Review of Custodial Transport Services in Western Australia (2007) 90-1, Recommendation 27.

279 Hope, above n 161, 89. Another more recent example of the WA Government's refusal to implement recommendations is the response to the report about strip searching in WA prisons. The WA Government does not support key recommendations, including phasing out 'routine strip searching' (recommendation 8) and using technology to 'reduce reliance on strip searching' (recommendation 10): OICS, Strip Searching Practices in Western Australian Prisons (2019) 32-3.

280 Government of Western Australia Department of Corrective Services, Annual Report 2010/11. Contract for the Provision of Court Security and Custodial Services (2011) 4-5. OICS conducted an audit of transportation, but the focus of the report is empirical data, rather than treatment of people during transport: OICS, Prisoner/Detainee Transportation 1 July 2011 - 31 December 2011 (2012).

281 There was a coronial inquest into five deaths in Risdon prison that occurred between August 1999 and January 2000: Magistrates Court of Tasmania, Findings. Deaths in Custody Inquest (2001); Two Ombudsman reports on an inquiry carried out in 2001: Ombudsman Tasmania, Report on an Inquiry into Risdon Prison. The Risdon Prison Complex (2001) and Ombudsman Tasmania, Report on an Inquiry into Risdon Prison. Risdon Prison Hospital \& Forensic Mental Health Service (2001); a 2010 Ombudsman inquiry: Ombudsman Tasmania, Risdon Prison Complex Tamar Unit and Behaviour Management Program. Investigation Report June 2010 (2010); and an independent inquiry conducted by Mick Palmer commissioned by the Minister for Corrections in 2010, which reported in 2011. The latter report and the government's response are available at Tasmania, Department of Justice, Corrective Services, Inquiry into the Risdon Prison Complex <http://www.justice.tas.gov.au/correctiveservices/risdonprisoninquiry>. It was the 2011 report that led to the eventual establishment of the Tasmanian Custodial Inspector. 
very large amount of money were to be spent on the facility, it is unlikely that it could ever conform to contemporary prison standards ${ }^{282}$ In 2010, the Ombudsman, writing about the Tamar Unit within Risdon, observed, as long as Tamar continues to operate as it has been, there is cause to be concerned for the mental and emotional wellbeing of the prisoners accommodated there'. ${ }^{283}$ It was the Tamar Unit that was the subject of the Pickett litigation in 2011 (discussed earlier in this chapter) where the practice of solitary confinement was found to breach both a common law duty of care and the Corrections Act 1997 (Tas). ${ }^{284}$

Three years later, in 2014, there were media reports suggesting that people were still being held in solitary confinement for 23 hours per day in Risdon Prison. ${ }^{285}$ A 2018 report by the TOCI found that all Tasmanian prisons were overcrowded and that this was leading to people having to spend more time in their cells in 'lock downs. ${ }^{286}$

The fourth and final example is the Victorian Government's failure to support the 2017 recommendation made by the Victorian Ombudsman that routine strip searching of women in the Dame Phyllis Frost Centre (that is, upon arrival and after all visits by non-professionals, such as family members ${ }^{287}$ ) cease and be replaced with 'a Charter-compliant practice of strip searching based on intelligence and risk assessment'. ${ }^{288}$ The Ombudsman noted that the searches were generally not leading to the identification of contraband and that alternatives could be used, such as body scanning. ${ }^{289}$ This would be consistent with Rule 20 of the Bangkok Rules, which provides that 'alternative screening methods, such as scans, shall be developed to replace strip searches and invasive body searches, in order to avoid the harmful psychological and possible physical impact of invasive body searches'.

282 Ombudsman Tasmania, Report on an Inquiry into Risdon Prison. The Risdon Prison Complex (2001) 3 .

283 Ombudsman Tasmania, Risdon Prison Complex Tamar Unit and Behaviour Management Program. Investigation Report June 2010 (2010) 4.

284 Pickett $v$ The State of Tasmania [2011] TASSC 907 (20 April 2011).

285 Matt Smith, 'Solitary Life for Risdon Prison Inmates', The Mercury (Tasmania), 14 June 2014.

286 Tasmanian Custodial Inspector, Annual Report 2017-18 (2018) 11.

287 Victorian Ombudsman, above n 6, 57.

288 Ibid 103, Recommendation 5.

289 Ibid 59. 
The Department of Justice and Regulation's response to this recommendation was:

While the General Manager of Dame Phyllis Frost Centre acknowledges the need to improve record keeping with respect to strip searching, the department does not consider that current practice with respect to observation and supervision of women changing into overalls before contact visits amounts to 'strip searching'. The department is also of the view that current supervision, observation and strip searching is Charter compliant. $^{290}$

The Ombudsman provided the following response to this response:

I am disappointed that the department has not accepted that this practice should stop unless justified by intelligence and risk. The claim that the women simply 'undress' prior to visits is at best misguided: they do so in the presence of two guards wearing latex gloves, consistent with a strip search. ${ }^{291}$

There are undoubtedly instances where monitoring bodies' recommendations do lead to positive changes in prisons because of the implementation of their recommendations. For instance, 18 of the 19 recommendations made by the Victorian Ombudsman about the Dame Phyllis Frost Centre were accepted by the department. ${ }^{292}$

However, there are far too many serious consequences arising from the failure to implement recommendations. A useful reform would be to introduce a legislative requirement for the responsible government to respond to the recommendations made by the organisations that form part of the NPM, and to do so within a specific timeframe. Precedents for this exist in Victoria. The Victorian Government is required to respond to coronial inquest recommendations within three months and to Joint Investigatory Committees of the Parliament's recommendations within six months. ${ }^{293}$ These are legislative requirements to respond, not necessarily to support, but they at least work to ensure that governments have turned their minds to the content of the recommendations and risks associated with ignoring them. Further, it would also be helpful if the

290 Ibid 103.

291 Ibid 5.

292 Ibid 102-6.

293 Coroners Act 2008 (Vic) s 52(6); Parliamentary Committees Act 2003 (Vic) s 36. 
monitoring organisation kept track of the implementation of their own recommendations (in the way that the Victorian Ombudsman does). ${ }^{294}$ Alternatively, a specific organisation could be given the responsibility to monitor the implementation of the recommendations of these bodies. ${ }^{295}$

\section{Concluding Remarks}

It is difficult to identify an Australian jurisdiction with external monitoring mechanisms that meet all of the OPCAT criteria. This is because even when there is regular, independent and expert-led monitoring leading to comprehensive and relevant recommendations made by monitoring organisations, the majority of jurisdictions have a poor record of implementing the recommendations. ${ }^{296}$

A second priority area for improvement - to meet the OPCAT criteriais to ensure monitoring bodies are adequately resourced to carry out their important functions. The reasons for this are self-evident.

Jurisdictions without prison inspectorates and proactive Ombudsmen (particularly the Northern Territory and Queensland) have the most work to do to meet the OPCAT criteria for NPM. If they do not wish to create a new body (such as a prison inspectorate), it is likely that these organisations would designate their Ombudsman or anti-discrimination commissions as the organisation responsible for prison monitoring as part of the NPM with responsibility for monitoring prisons. Either way, they will need to draw on the experience of other jurisdictions that are further advanced in this area. There are some examples of good practice to draw on, such as the Inspector of Custodial Services Act 2017 (ACT) and the detailed standards published by the Inspector in 2019.

The path ahead for all Australian jurisdictions may also be further informed by the OPCAT-compliant inspection of a Victorian prison that has been conducted by the Victorian Ombudsman. The Ombudsman's

294 Victorian Ombudsman, Ombudsman's Recommendations. Third Report on Their Implementation (Report for Parliament, 19 February 2014).

295 For example, the Victorian Inspector-General for Emergency Management is tasked with reporting on the implementation of the recommendations made by the Victorian Bushfires Royal Commission.

296 It is too early to assess how the ACT Government will respond to recommendations by the ACT Inspector of Custodial Services, but at the national level, the record of implementation of recommendations by prison monitoring bodies is poor. 
office developed practical tools, including a detailed survey for imprisoned people and staff, and an aide memoire for inspection staff, which are appended to the report. ${ }^{297}$

\section{Summary and Conclusion}

At first glance, it may seem that the OPCAT has nothing to add to the multitude of monitoring bodies involved in prison oversight in Australia-courts, inspectorates, Ombudsmen, human rights and anti-discrimination commissions, Coroners, Royal Commissions and parliamentary committees. But a closer examination reveals that the existing monitoring and investigatory regime has not been sufficient to protect the human rights of imprisoned people. The many concerning practices documented in this chapter make clear that these existing oversight organisations have not, despite numerous sensible recommendations, been able to rectify violations of rights, much less prevent them from occurring in the first place.

There are three problems facing Australia in relation to prison monitoring at present. First, it occurs at the domestic level only, without insight or involvement from international human rights monitoring experts. Second, it is predominantly reactive, rather than preventive in focus (although this has improved with growing numbers of jurisdictions introducing dedicated prison inspectorates). Third, there are serious deficiencies in meeting the six criteria for NPMs set out in the OPCAT. When those criteria are not met-particularly implementation of recommendationsthe consequences are not merely repeated human rights violations in Australian prisons. These violations include deaths and significant harms to people in Australian prisons.

Ratification of the OPCAT is a distinct opportunity for this situation to be rectified. It has the potential to solve all three problems currently faced. First, it introduces international monitoring by the SPT, which is a UN committee of experts that will inspect Australian prisons and 'advise and assist' Australia with the establishment of its NPM. ${ }^{298}$ Second, it will shift

297 Victorian Ombudsman, above n 6, 107-32 (Appendix 1 'Prisoner Survey'; Appendix 2 'Staff Survey'; Appendix 3 'Aide Memoire (Health and Wellbeing)').

298 OPCAT art 11. Bearing in mind the limitations of this mechanism stemming from the infrequency of visits. 
the focus on monitoring at the national level by the NPM to preventive issues, in accordance with the OPCAT. Third, it will require that the NPM meet the six criteria specified in the OPCAT: (1) independence; (2) expertise; (3) adequate resourcing; (4) regular visits with the aim of providing protection against torture and other cruel, inhuman or degrading treatment or punishment; (5) functions and powers; and (6) implementation of recommendations.

In this way, the OPCAT has the potential to revolutionise the prison monitoring landscape in Australia. It is appropriate to conclude with the aptly written words of the Victorian Ombudsman in their report on the OPCAT-compliant inspection of a Victorian prison:

The ratification of OPCAT is an important symbol of Australia's commitment to human rights. Its implementation, through setting up, resourcing or empowering independent agencies, is equally important in ensuring that commitment is not merely symbolic. 299 
This text is taken from Towards Human Rights Compliance in Australian Prisons, by Anita Mackay, published 2020 by ANU Press, The Australian National University, Canberra, Australia.

doi.org/10.22459/THRCAP.2020.03 